\title{
Kimberley points of Western Australia: Pressure flaking, projections and prestige
}

\author{
Tim Ryan Maloney \\ Griffith Centre for Social and Cultural Research, School of Humanities, Languages and Social Science, Griffith \\ University, Gold Coast campus, Queensland, Australia. Email: t.maloney@griffith.edu.au
}

\begin{abstract}
:
Kimberley points are pressure flaked bifaces with marginal projections, produced within the last millennium, in north Western Australia. These points were hafted for hunting and fighting in recent times, although there is some suggestion that smaller points tended to be hafted for use in favour of larger points, which were reserved for trade and exchange. Kimberley Points are imbued with strong social signalling and prestige qualities, known from Historic times. This paper examines whether these qualities are reflected archaeologically in their marginal projections produced with pressure flaking; and their morphology and production. Multiple sources of Kimberley Point archaeology, ethnography, and production are critically reviewed. As prestige items, the marginal projections are found to very likely relate to their social value, rather than functional drive, which this study investigates using morphological approaches. Samples from both ethnographic collections and archaeological surface assemblages are analysed. The study finds that biface elongation, length and perimeter length each greatly influenced the number of and size of marginal projections, regardless of raw material. This aspect of production probably reflects the value and social prestige for large serrated points, likely produced by the knapper before an audience in virtuoso displays of pressure flaking. It is conceivable that these complex social practices emerged around 1,000 years ago. This study provides a rare glimpse into the social values of stone tool produces, and links archaeological data to social values in the past.
\end{abstract}

Keywords: biface; pressure-flaking; Kimberley Points; Australian archaeology; stone tools

\section{Introduction}

\subsection{Kimberley Points}

Kimberley Points are pressure flaked bifaces (Figure 1) produced within the Kimberley region of northern Western Australia (Figure 2). They are recognized by characteristic pressure flaking with marginal projections. Variation in these projections and the role they play in Kimberley Point social values, is examined in this study. Kimberley Point archaeology, ethnography, and production is critically reviewed. Chiefly, I seek to test the hypothesis that marginal projections on these bifaces are related to social prestige and signalling, rather than function.

Published by the School of History, Classics and Archaeology, University of Edinburgh ISSN: 2055-0472. URL: http://journals.ed.ac.uk/lithicstudies/ 
Kimberley Points are first widely archaeologically visible around 1,000 cal. BP (Maloney et al. 2014). They were collected in the $19^{\text {th }}$ and $20^{\text {th }}$ century, when these items were part of an elaborate Indigenous trade network called Wunan, which extends across the entire north-west region (Akerman et al. 2002; Blundell 1975: 403; Blundell \& Woolagoodja, 2005: 129; Redmond 2012). During the early $20^{\text {th }}$ century production rates probably proliferated when trade for European commodities, such as flour, tobacco, and new raw materials, were adopted by Aboriginal societies (Akerman et al. 2002: 22; Harrison 2002: $358,364)$. During the latter half of the $20^{\text {th }}$ century, Kimberley Points were extensively collected for museums (Akerman 2008; Harrison 2006). Largely from museum collections, Akerman and Bindon (1995: 13-14) identified Kimberley Points with serrate or denticulate margins, as well as Kimberley Dentate Points. These three groups are examined morphologically for the first time in this study.
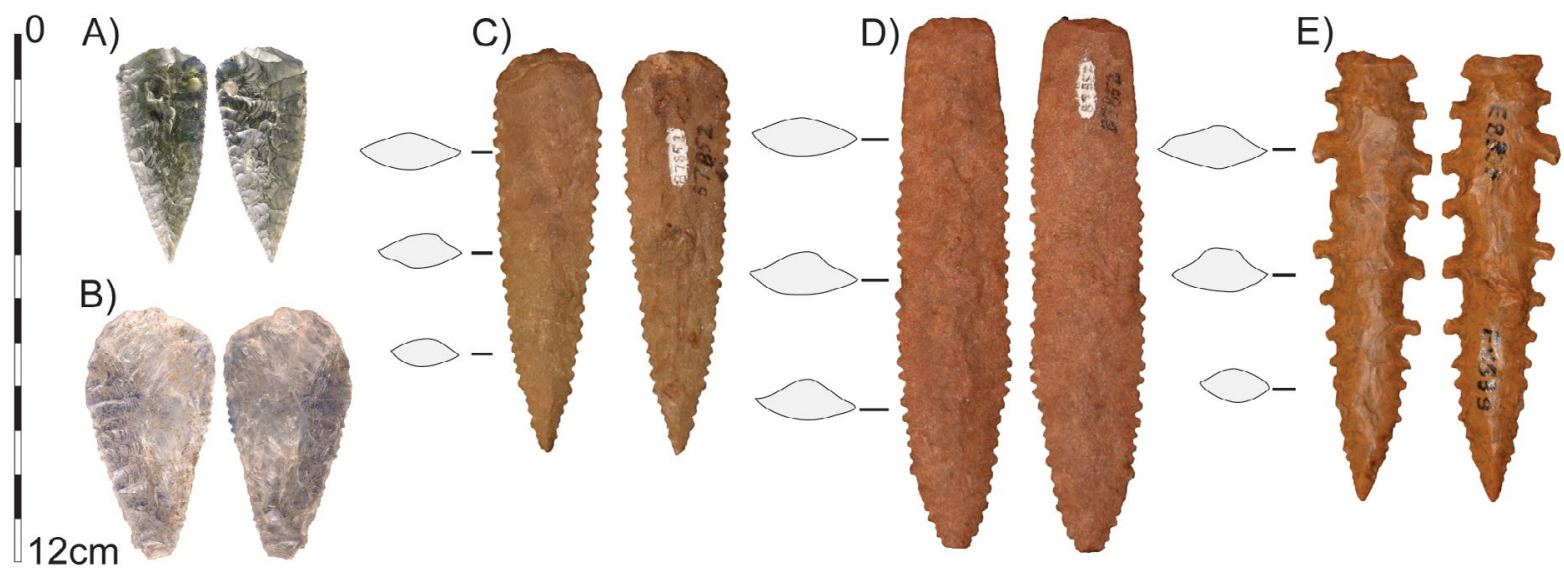

Figure 1. Pressure flaked bifaces (a.k.a. Kimberley Points). A) Bottle glass Kimberley Point with serrate margins from Historical period (McSherry's Gap Figure 2) B) Crystal quartz Kimberley Point with serrate margins (Mt Behn Figure 2) C) Quartzite Kimberley Point with serrate margins (3D model available as object file) D) Quartzite Kimberley Point with serrate margins E) Chert Dentate Kimberley Point with dentate and serrate margins (collected near Wolf Creek Figure 2). The scale bar is $12 \mathrm{~cm}$ long divided into $1 \mathrm{~cm}$ segments.

Isolated Kimberley Points, identified by these characteristic margins, were historically observed in parts of the Northern Territory such Wardaman Country (Davidson 1935: 170), Port Keats (Falkenberg 1968: 19, 24; cited in Akerman 2008: 75), the Tennant Creek area (Spencer 1928: 17, fig. 147), the Alligator Rivers (Akerman et al. 2002: 22), Central Desert regions (Gould 1980: 141-143; Spencer 1928: 510-511; Spencer \& Gillen 1904: 675-676), the Gibson Desert region (Akerman et al. 2002: 18), the Western Desert (Tindale 1985: 12), and as far east as central Queensland (Akerman \& Stanton 1994: 17), and the Gulf of Carpentaria (Davidson \& McCarthy 1957: 450) - see Figure 2 A. Manufacture outside the Kimberley region occurred in Wardaman country within the last 300 years (Clarkson 2007: 157; Davidson 1935: 170), Rottnest Island prison off the coast of Perth in the $20^{\text {th }}$ Century (Harrison 2002: 361-363), the Dampier Peninsula in the $20^{\text {th }}$ Century (personal communications with Akerman, in July 2012), and Barrow Island, probably during the pearling industry in the mid-20 ${ }^{\text {th }}$ century (Hunter 2014). Accounts of manufacture outside of the Kimberley region by Davidson (1935), may imply a lack of technical proficiency by the Wardaman men, who lacked the skills of initiated Kimberley men in point production (Davidson 1935; see also Moore 2015).

Kimberley Points were hafted for hunting and fighting in recent times (Akerman et al. 2002: 21), and there is some suggestion that smaller points tended to be hafted for use in favour of larger points, which were reserved for trade and exchange (Akerman 1978; Harrison 2006: 64). 


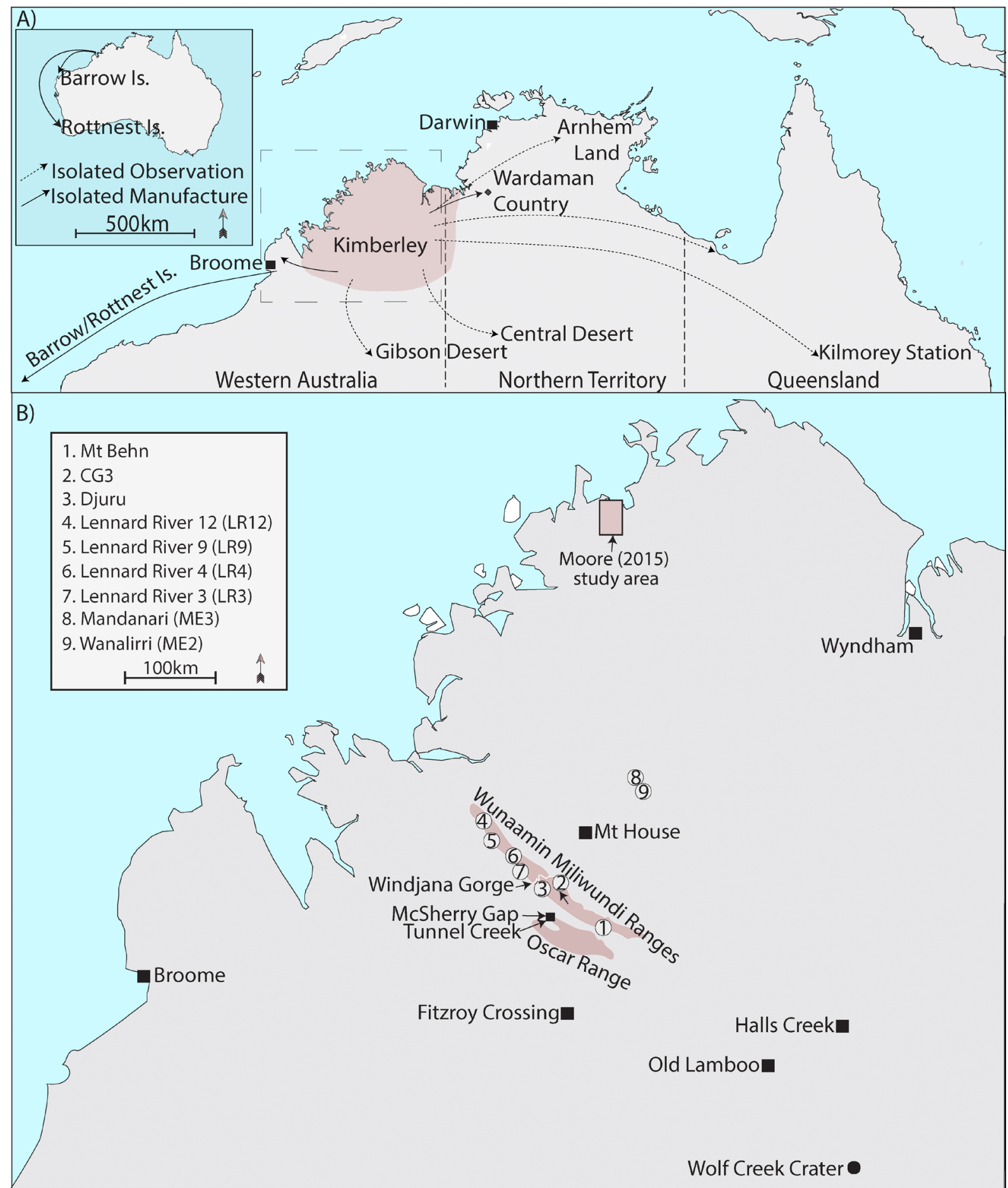

Figure 2. A) Map of northern Australia showing approximate boundary of Kimberley Point distribution, including isolated observations associated with trade (dashed line) and known manufacturing areas post contact (solid line). B) Kimberley inset showing site locations used in study and major towns and ranges associated with collections.

Kimberley Points are rarely recovered in datable contexts or deposits, although the few examples recovered ( $\mathrm{n}=16$, from 10 excavated sites) have been consistently found associated with age estimates of 1,000 cal. BP or less (Maloney et al. 2014). From these few Kimberley Points, we know that serrate and dentate marginal projections were produced in prehistoric times, as shown by those recovered by Maloney et al. (2014), reproduced in Figure 3. The largest collections available are ethnographically collected, typically involving isolated points 
with minimal provenance. This study uses such collections to explore morphological variability amongst Kimberley Points with marginal projections and examines links to social values.
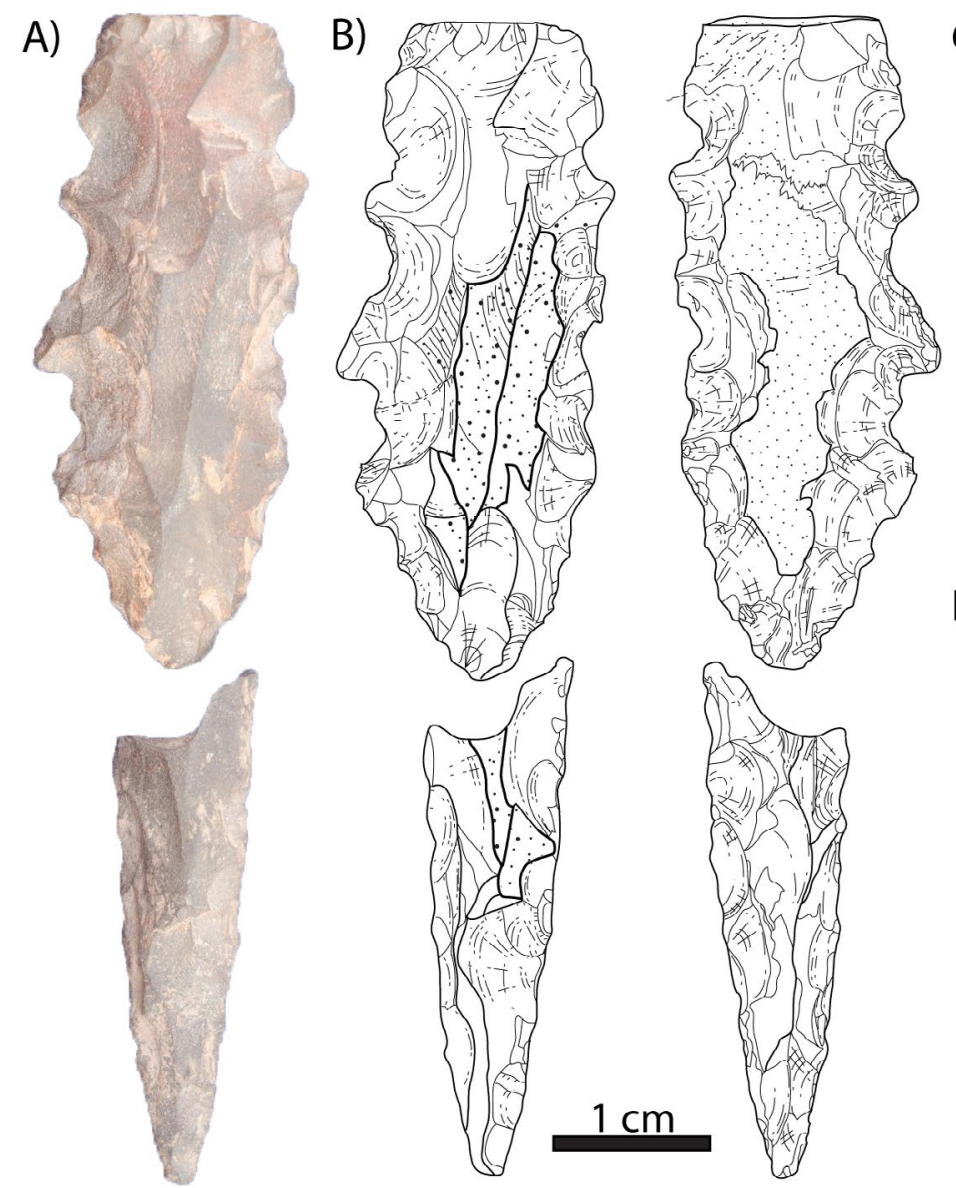

C)

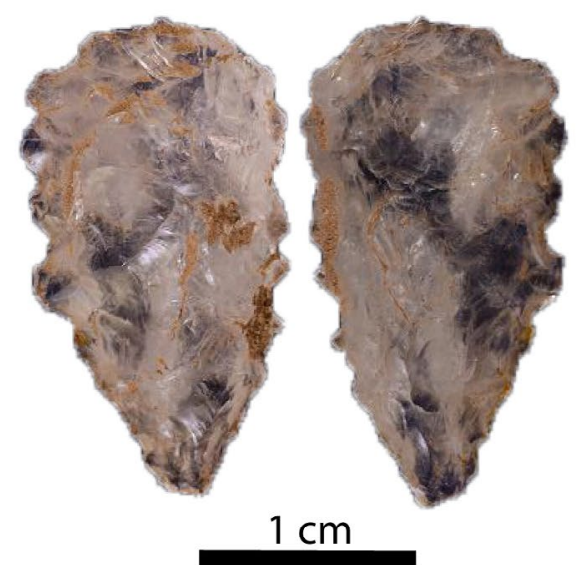

D)

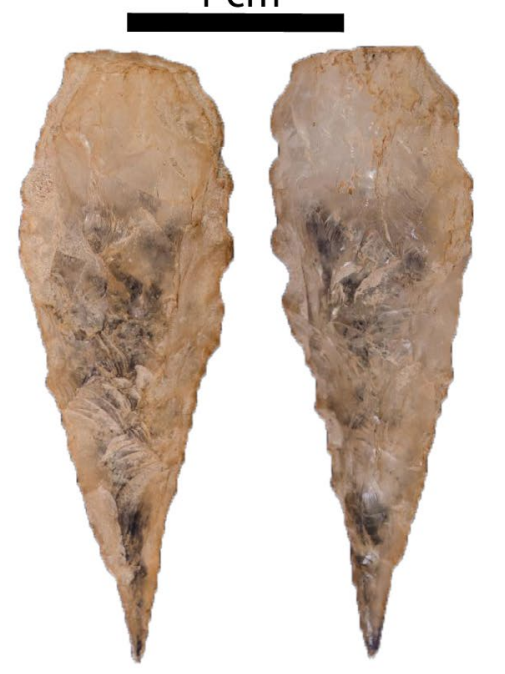

Figure 3. Examples of archaeologically recovered Kimberley Points from Maloney et al. (2014): A) Kimberley Dentate Point recovered from Mt. Behn B) Mt. Behn point sketch C) Kimberley Point (serrate) from CG3 D) Kimberley Point (serrate) recovered from Djuru.

\subsection{Projections, social values, and function}

The link between social values and marginal projections are not direct. Highly visible items used in public contexts can generally be considered social signals, to varying degrees (e.g., Carr 1995; Steiner 2014). Around the world, non-functional explanations for bifacial point serrations have included burials and ceremonies (Johnson 1940), trade goods (Akerman et al. 2002), tribal affiliation and symbols of social membership (Hoffman 1997: 214-218; Loendorf et al. 2015; Moore 2015).

Other researchers have speculated that serration might represent functional advantages for hunting and fighting weapons (Rots et al. 2017: 54). Loendorf et al. (2015) has used experimental data to demonstrate that serrations offer no functional advantage, suggesting that projectile accuracy, wound size and durability, are in no way improved. Akerman et al. (2002: 21-22) residue study, does not suggest the Kimberley Point serrations themselves provided any functional advantages. The fragility of large serrated points has also been noted (Haury 1976: 297).

Marginal projections from Middle Stone Age southern Africa, have been found to be a consequence of greater flaking control in projectile weaponry (Rots et al. 2017). While undoubtedly pressure flaked, none of these early bifaces resemble the elaborate efforts to 
produce as many marginal serrations as those found on Kimberley points (Rots et al. 2017: 34-39). Instead, MSA researchers found pressure flaking 'occurred together with heat treatment...to create straight and regular tip sides' and suggest greater flaking control as the driver of early pressure flaking (Rots et al. 2017: 48). In terms of possible function, these authors suggest serrations might increase haemorrhage on game targets, and also possible help retain poison additives (2017: 54). These functional attributes can only be tested with residue analyses. So far, the only such study conducted on Kimberley Points (Akerman et al. 2002) has not found strong evidence to support either hypothesis.

Proceeding on the assumption that Kimberley Point marginal projections do not offer a functional advantage, I follow Hoffman (1997) and Loendorf et al. (2015), in examining social signalling as a driver of the need for this unique pressure flaking. Similar to Hoffman's (1997) study, the often decorated and highly visible shafts of Kimberley Points (see Akerman 1978; Akerman et al. 2002) are not included in the analysed samples here, although would support greater visibility for social signalling.

\subsection{The Kimberley Point production process}

Until recently, manufacture and morphological variability of Kimberley Points was largely inferred from ethnographic and historical observations of parts of the production process (Balfour 1903, 1951: 274; Basedow 1925: 367-370; Elkin 1948: 110-113; Indriess 1937: 59-62; Kaberry 1939: 16, 165; Love 2009: 93-95; Mitchell 1949: 64; Petri 2011 [1954]; Spencer 1928: 510-511; Tindale 1985: 8-11). Ethnographic observations combined with recent archaeological studies (Akerman \& Bindon 1995: 94-95; Akerman et al. 2002: 18-20; Maloney 2015: 196-226; 2019; Moore 2015) demonstrate a staged or teleological manufacturing process for Kimberley Points. Maloney (2019: 43-45) and Moore (2015: 917) have provided detailed production models, recognizing 5 main production phases.

Moore (2015: 924-925) found 5 production phases for Kimberley Points in his northwest study area (Figure 2). These phases align with those proposed by others (Akerman et al. 2002; Maloney 2015: 196-235). Maloney (2019: 43-45) expanded on these production stages, referred to as procedural units, to extract signals of the teaching and learning process; seeing extra production cues added which reflect the use of different manufacturing techniques and percussors. The most archaeologically visible manufacturing stages are best represented by Moore's (2015) five production phases. Table 1 summarises both production models, listing these production phases.

\subsection{Marginal projections on Kimberley Points}

With archaeological data now being used to model Kimberley Point production in such detail (e.g., Maloney 2019; Moore 2015), this paper explores the final production phase where marginal projections are added with fine pressure flaking. Unlike studies which treat all such marginal projections as generically similar (Rots et al. 2017), there is recognition of three qualitative types of projections on Kimberley Points (Akerman \& Bindon 1995: 13-14). These characteristic features were added in public displays of virtuoso knapping, later observed in historic times (Lommel 1997 [1952]: 5; Love 2009 [1936]: 93; Petri 2011 [1954]: 30; Tindale 1965: 154-157; 1985: 8). Harrison (2002: 369) provides an account, although not primary, of pressure flaking and prestige, at meetings on Old Lamboo station (Figure 2b):

...During interlanguage group meetings...men would lay out their finest Kimberley Points on the ground for others to admire, later, holding their spears fanned out behind them like peacocks' feathers as part of the display of point manufacture...(Harrison 2002: 369) 
Table 1. List of production phases by Moore (2015) and procedural units by Maloney (2019).

\begin{tabular}{|c|c|c|c|}
\hline $\begin{array}{l}\text { Production } \\
\text { phase }\end{array}$ & Description & $\begin{array}{l}\text { Procedural } \\
\text { unit }\end{array}$ & Description \\
\hline \multirow[t]{2}{*}{1} & \multirow{2}{*}{$\begin{array}{l}\text { Procuring a quartzite blank } \\
\text { for bifacial reduction. Large } \\
\text { tabular pieces from bedrock } \\
\text { edges. }\end{array}$} & 1 & $\begin{array}{l}\text { Biface blanks could be either tabular pieces or large } \\
\text { flakes. }\end{array}$ \\
\hline & & 2 & $\begin{array}{l}\text { Each initially requiring different preparation } \\
\text { knapping techniques using direct percussion }\end{array}$ \\
\hline \multirow[t]{2}{*}{2} & \multirow[t]{2}{*}{$\begin{array}{l}\text { Thinning and initially } \\
\text { shaping the blank. }\end{array}$} & 3 & $\begin{array}{l}\text { Blanks were thinned using direct percussion, } \\
\text { adjusting flake removals to suit blank morphology. }\end{array}$ \\
\hline & & \multirow[t]{2}{*}{4} & Relatively thin morphology accomplished with an \\
\hline 3 & $\begin{array}{l}\text { Regularizing the biface } \\
\text { proportions by percussion } \\
\text { contour flaking. }\end{array}$ & & $\begin{array}{l}\text { invasive flaking technique; initiated close to the } \\
\text { margins of the biface and propagating transversely. }\end{array}$ \\
\hline \multirow[t]{3}{*}{4} & \multirow{3}{*}{$\begin{array}{l}\text { Continuation of the } \\
\text { regularization and shaping } \\
\text { in phase } 3 \text { using invasive } \\
\text { collateral pressure-flaking. }\end{array}$} & 5 & $\begin{array}{l}\text { Manufacturing a bone or wood pressure flaking tool } \\
\text { (metal used in historic period). }\end{array}$ \\
\hline & & 6 & $\begin{array}{l}\text { Collateral pressure flaking further thinning the } \\
\text { biface }\end{array}$ \\
\hline & & 7 & $\begin{array}{l}\text { Pressure flaking technique involved anvil resting to } \\
\text { immobilize the biface, and insulation such as paper } \\
\text { bark. }\end{array}$ \\
\hline \multirow[t]{3}{*}{5} & \multirow{3}{*}{$\begin{array}{l}\text { Finishing by the non- } \\
\text { invasive pressure-flaking } \\
\text { technique to produce an } \\
\text { acute biface tip and } \\
\text { marginal denticulations or } \\
\text { serrations. }\end{array}$} & 8 & $\begin{array}{l}\text { Manufacture of a different, flat ended pressure } \\
\text { flaking tool. }\end{array}$ \\
\hline & & 9 & $\begin{array}{l}\text { Pressure flaking the fine biface margins to produce } \\
\text { projections of serrate, denticulate or dentate shape. }\end{array}$ \\
\hline & & 10 & Incorporated into composite tool. \\
\hline
\end{tabular}

Direct historic accounts of the final pressure flaking stage as a performance are rare, although often commented on by observers (Love 2009 [1936]: 93-95; Petri 2011 [1954]: 31; Tindale 1965: 56), suggesting a highly public atmosphere for this skill. There is as strong impression that this final pressure flaking stage was performed before a captivated audience in rock shelters and other sites, viewed by all members of the social group (Harrison 2002: 369; Idriess 1937: 60; Moore 2015).

Variation in the Kimberley Point marginal projections have hitherto not been explored with morphological approaches. Akerman and Bindon (1995: 13-14) outlined three qualitative modes of marginal projections for Kimberley Points: serrate, denticulate, and dentate (Figure 4). They define serrate margins as extremely small or fine projections, usually triangular in outline, and separated from each other by equally fine notches. Denticulate margins are regularly spaced projections separated by notches that are of similar or narrower width than the projections. It was also stated that Kimberley Points (serrate) have about 6 - 8 projections per $10 \mathrm{~mm}$ and Kimberley Points (denticulate) have around 2 - 3 per $10 \mathrm{~mm}$ (Akerman \& Bindon 1995: 14). Dentate projections are separated by notches that are wider than the projections. Thus, the qualitative modes are Kimberley Points (serrate), Kimberley Points (denticulate) and Kimberley Dentate Points. How these groups vary morphologically has never been explored. This paper will focus on how the marginal projections vary amongst Kimberley Points using morphological approaches and explains new aspects of the design and social role of pressure flaked bifaces in Australia.

The Kimberley Point pressure flaking technique is unlike those found in the Americas (e.g., Crabtree 1966; Johnson 1940; Shott 2017- see Nelson 1916 for description of Ishi technique); and involved a unique orientation of the pressure flaker. The left hand loading the force is held over rather than adjacent to the edge being worked (Akerman et al. 2002: 19; Blundell \& Woolagoodja 2005: 128; Elkin 1948; Tindale 1965; 1985: 32); demonstrated in 
Figure 5 A. This technique is also demonstrated in the logo of the Journal of Lithic Studies, based on a drawing by Valerie Waldorf for Mark Moore.

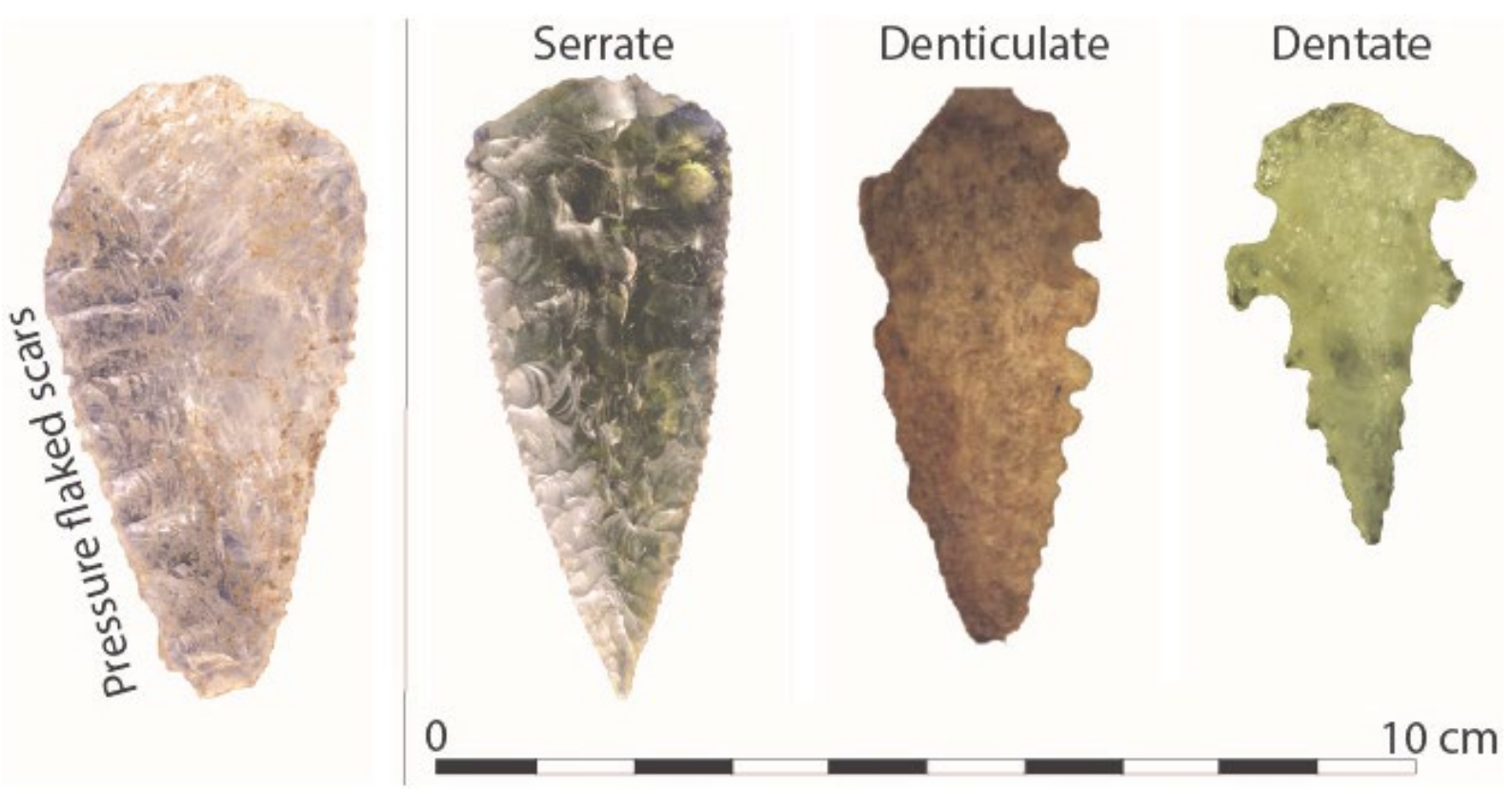

Figure 4. Examples of pressure flaked bifaces (a.k.a. Kimberley Points) from the study area conveying: A) Collateral pressure flaked scars - Mt Behn, B) Kimberley Point (serrate) - McSherry's Gap, C) Kimberley Point (denticulate) - LR9 and D) Kimberley dentate Point - LR12.
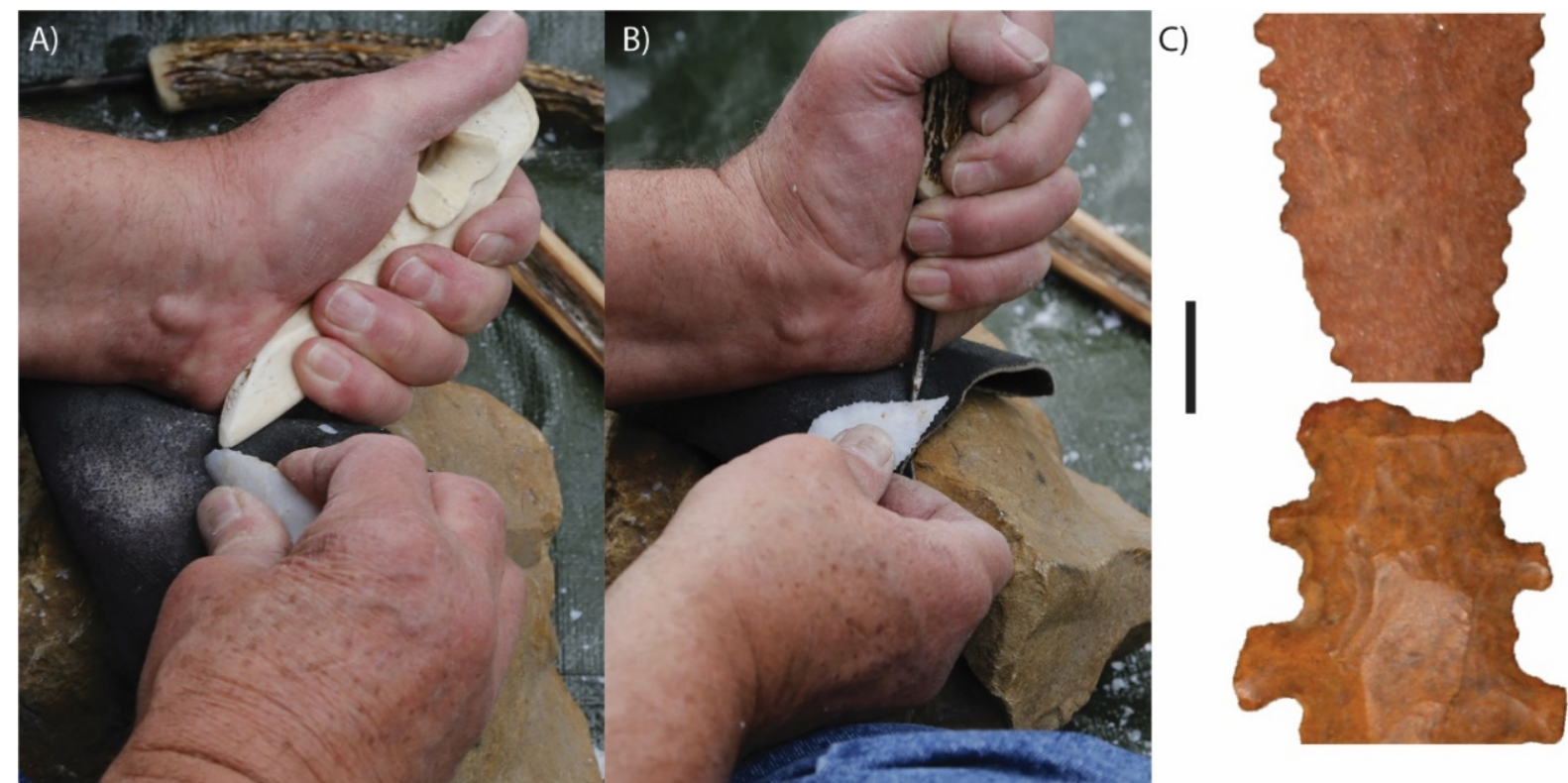

Figure 5. Orientation of pressure flaking tools. A) Large bone pressure flaker used to remove invasive collateral pressure flakes. B) Fine chisel ended metal pressure flaker, used to create serrate marginal projections. C) Semicircular flake scars adjacent to marginal projections. Scale bar is $1 \mathrm{~cm}$.

The removal of invasive, collateral flakes (Figure $4 \mathrm{~A}$ ) using this technique, involved larger bone or wood pressure flakers (Love 2009 [1936]: 93-95), like that shown in Figure 5 A. The final stage of pressure flaking used a flat ended bone or metal tool, orientated in the same way, as demonstrated in Figure $5 \mathrm{~B}$. This technique removed small, semi-circular flakes to create notches, with smaller flakes removed for serrate projections, and larger ones for 
dentate (Figure $5 \mathrm{C}$ ). The creation of each projection requires two or more flakes removed in this fashion.

This technique is not the same as "raking", whereby, applied pressure at an oblique angle along the thin edge of a biface can result in a fine, serrate retouch pattern (Högberg \& Lombard 2016; Patterson 1998: 30; Titmus 1985). According to experimental data, flake scars resulting from pressure flaking with a hand-held indenter, produce deeper and more concave flake scars, than raking scars (Patterson 1998: 29, figs 3-5). The roll over technique described by Tindale (1965: 156) has no known parallel.

\subsection{Prestige and projections}

Several commentators have noted Kimberley Points are loaded with social and symbolic information (e.g., Akerman et al. 2002: 15-17; Love 2009 [1936]: 96; Tindale 1965: 154-156) and were widely observed as being part of initiation rites (Kaberry 1939: 14, 232; Love 2009 [1936]: 95-96; Petri 2011 [1954]: 151-160; Tindale 1965: 154-155). Kimberley Points and the ability to produce them were closely tied to Wanjina religion (also expressed in rock art: Blundell \& Woolagoodja 2005) and Wunan exchange systems (Akerman et al. 2002; Blundell \& Woolagoodja 2005: 129). These observations alone should negate claims that in recent times, Kimberley Points "essentially came to function as virtuoso tourist art" (Harrison 2006: $63)$, during the period of $20^{\text {th }}$ century collecting.

The leading explanation for the innovation and proliferation of Kimberley Points, is an association with prestige and social signalling (Moore 2015), not shared with earlier, nonpressure flaked points (e.g., Maloney et al. 2017a). It has been further argued that this innovation occurred during a time of reduced foraging risk and increased social interaction, when pressures to maintain longer tool use lives diminished and social connectedness spread (Maloney 2019; Maloney et al. 2017a; Hiscock \& Maloney 2017). In historic times, the act of highly skilled pressure flaking appeared to be an established and widespread practice of garnering personal prestige (Akerman 1978: 489; Harrison 2002; Spencer 1928: 511; Tindale 1985: 11).

Moore (2015) argues that the initial thinning phases of biface production was conducted in private and kept secret, and only the later pressure flaking phases were conducted in virtuoso demonstrations by expert knappers, to gain prestige. Moore (2015) mainly draws on ethnographic and historical records, where accounts of pressure flaking by experts are most often in public contexts, and direct percussion most often in other, more private contexts. Other researchers would argue this operation is less than secret (personal communications with Akerman in July 2019), yet often conducted in initiated male social groups, associated with teaching and learning Kimberley Point production (see Maloney 2019) - thus non-public. The complex nature of teaching and learning, and scaffolding included in Kimberley Point production, required private tuition and repeated practice for initiated Kimberley men (Maloney 2019).

Morphological aspects of Kimberley Points have also been associated with prestige and social signalling. For example, point length was related to prestige among historic Kimberley knappers, with points measuring longer than $50 \mathrm{~mm}$ being made specifically for exchange, by master craftsmen (Akerman 1979: 149-150; Akerman et al. 2002: 21). Marginal projections themselves may have increased in historic times, perhaps for trading purposes (Akerman et al. 2002: 26; Harrison 2004: 6).

\section{Methods}

To explore marginal projection variability with a morphological approach, a series of quantitative measures were recorded (Figure 6) for complete points. Measurements include 
the total number of marginal projections and number of projections per millimetre of biface edge. The average length of each marginal projection was measured as the maximum lateral projection between the adjacent notches (Figure 6), divided by the total number of marginal projections. The average distance between each projection was also calculated, by measuring the distance between the centres of each projection, divided by the total number of projections (Figure 6). The same procedure was followed for distances between notches (Figure 6). These measures were compared with the three qualitative projection types outlined by Akerman and Bindon (1995: 89). Projections and their variability were also compared with biface perimeter length, biface length, elongation, and three measures of relative thickness, taken as width divided by thickness at three points along biface length (Figure 6). Comparison of these morphological measures used statistical tests (SPSS v25), with normality tests performed to determine appropriate tests for variables, which include Mann Whitney, Kruskal Wallis, Wilcoxon signed rank, and Analysis of Variance.

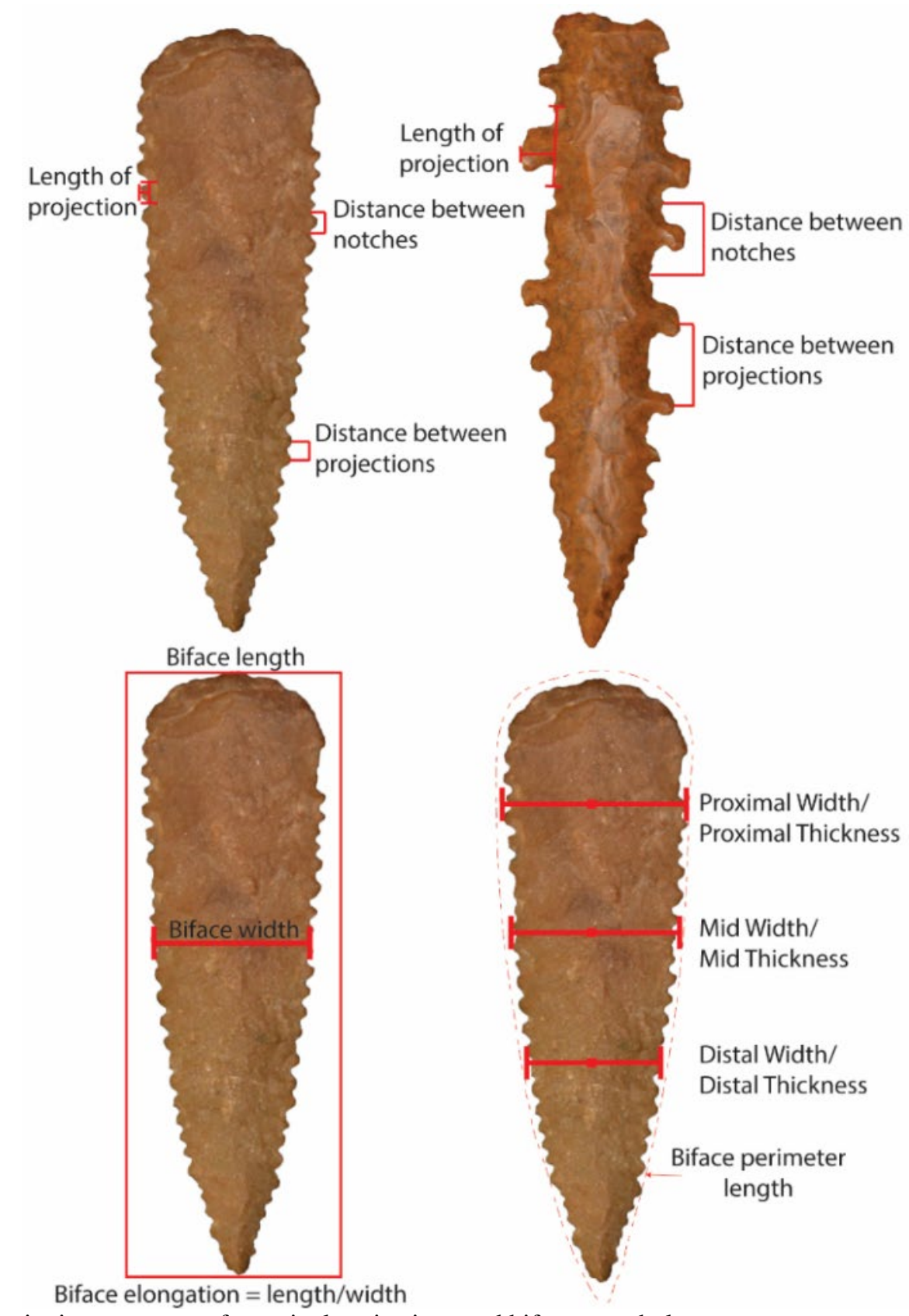

Figure 6. Quantitative measures of marginal projections and biface morphology. 


\section{Samples}

Due to paucity of recovery in archaeological deposits, there will likely never be an appropriate sample size of Kimberley Points, with which comparison with those from historical times could be made. Instead, this study will compare a sample of ethnographically collected points, with archaeological surface collections. Historic materials such as glass, ceramic, and metal are the only reliable temporal indicator, as stone Kimberley Points could be manufactured anytime within the last millennium.

The first sample includes the Western Australian Museum's (WAM) Kimberley Point collection (ethnographic collection hereafter), collected between the 1890s and 1990s, by various anthropologists, pastoralists, tourists, and museum curators. Analysis attempted to focus only on these reported to have been collected from the southern Kimberly, for some spatial consistency. These collectors would typically collect finished artefact forms such as axes and Kimberley Points, seeing the catalogue reflect a trend towards Kimberley Points collected in isolation, without any of the manufacturing debris. One exception to this, is the collection of paperbark wallets; consisting of a paperbark (melaleuca $s p$.) sheet rolled to contain bifaces and percussion tools (Akerman et al. 2002). One example from Tunnel Creek is included in this sample - containing nine glass and two ceramic bifacial preforms, as well as a single complete Kimberley point and pressure flaking tools. Spatial information is usually limited to major landmarks and places, such as stations, rivers, ranges or towns. This sample $(\mathrm{n}=99)$ includes 57 Kimberley Points with marginal projections and 24 bifacial preforms (Table 2). Analysis excludes 18 points where transverse snaps or adhering resin, prevent morphological measures. These artefacts were all initially labelled as 'spear head' when entered into the WAM catalogue, although Table 3 lists the frequency of artefacts according to the projection type groups and bifacial preforms used here.

To explore how Kimberley Points were produced throughout the study area, a second archaeological sample was also analysed. Valda Blundell (1975) conducted archaeological survey, excavation, and surface collection throughout the southern Kimberley, with artefacts now housed at WAM. The Blundell (1975) collection used in this study includes 4 sites along the Oscar Napier Range, and two others from Mount Elizabeth (Figure 2), listed in Table 4. Unlike the ethnographic collections, the Blundell collection contains biface production phases, flaking debris, many other non-biface stone tools, and percussion tools (see Maloney 2015: 338 for full description of the artefacts excluded from this study). The Blundell collection sites depicted in Figure 2 (LR12, LR9, LR4, LR3, ME2 \& ME3), encompass Ungummi, Bunuba and Ngarinyin country. None of the Blundell (1975: 201, 305) collection excavations were dated, although each contain glass, ceramic and metal. It is likely that Kimberley Points were removed from some of the Blundell collection sites, before she visited them in the early 1970s. Both Mandanari (ME3) and Wanaliri (ME2) for example, were visited by a German anthropologist during the Second World War, which Blundell (1975: 193) suggested was Lommel (Lommel 1997 [1952]). Ian Crawford, the Western Australian Museums' first archaeology curator, is also known to have visited these sites in the early 1960s (Crawford 1968: 40-42, 107-109). It is likely that both would have collected Kimberley Points.

Table 4 lists the bifacial preforms and Kimberley Points identified in the surface collections of these sites. LR12 was the furthest west along the Napier Range of the sampled Blundell collections (Figure 2). The site is a large limestone rock shelter, with an extensive surface collection (Blundell 1975: 232-236), where 10 bifacial preforms and 3 pressure flaked points were collected. LR9, also a large limestone rock shelter in the Napier Range, was Blundell's (1975: 218-221) largest surface collection, including over 10,000 stone artefacts, although recovering only two pressure flaked points. LR4 is a rock shelter immediately 
adjacent Burralumna Spring, where a single Kimberley Point was collected (Blundell 1975: 213). LR3 is a small shelter, also within the Napier Range, where Blundell (1975: 212) collected a single Kimberley Dentate Point. The Ngarinyin names for the Mount Elizabeth sites are Mandanari (ME3) and Wanaliri (ME2) (Blundell 1975: 197-198). Wandjina figures are found in the rock art at each of these sites (Blundell 1975: 198-199, fig. 4).

Table 2. Ethnographic collection from the southern Kimberley, listing collectors, collection date and WAM catalogue numbers. n/a depicts information not available. Abbreviations: * Collected from Moongaroonggoo (Maloney et al. 2017b); NA - not available

\begin{tabular}{|c|c|c|c|c|}
\hline Collector & $\mathbf{n}$ & Collection Date & Location information & Catalogue numbers \\
\hline A.H. Green & 4 & $\begin{array}{l}27 \text { October } 1936 \\
27 \text { February } 1947\end{array}$ & Fitzroy River Valley & $\begin{array}{l}\text { E10864, E10859, E10858, } \\
\text { E10184 }\end{array}$ \\
\hline Butler & 13 & $\begin{array}{l}\text { June } 1965, \\
\text { October } 1973\end{array}$ & $\begin{array}{l}\text { Tunnel Creek \& Saddles Spring } \\
\text { Mt. House }\end{array}$ & B2342, A15937 \\
\hline Ian Crawford & 3 & 15 October 1961 & $\begin{array}{l}\text { Lennard River north, Painted } \\
\text { Rock* peripheral collection Fossil } \\
\text { Downs }\end{array}$ & B6306 \\
\hline D Odgers & 1 & 1966 & NA & A16347 \\
\hline D Merrilees & 24 & 24 October 1964 & Wandjina Gorge & A15803 \\
\hline $\begin{array}{l}\text { Douglass \& } \\
\text { Kenderick }\end{array}$ & 1 & 5 July 1966 & Wandjina Gorge West End & A16312 \\
\hline E Mitchell & 9 & $\begin{array}{l}14 \text { April 1930, } \\
25 \text { October } 1913\end{array}$ & King Leopold Ranges & $\begin{array}{l}\text { E09551, E09550, E09558, } \\
\text { E09552, E09549, E5536, E9547 }\end{array}$ \\
\hline H Furrmann & 1 & NA & Wolf Creek Junction & A9790 \\
\hline G.H. Bostock & 4 & 1887 & Napier Range & A10412, A10413, A10408 \\
\hline $\begin{array}{l}\text { Government } \\
\text { Geologist }\end{array}$ & 1 & 30 December 1922 & King Leopold Ranges & E088459 \\
\hline GW Kendrick & 2 & $\begin{array}{l}3 \text { August } 1967 \text {, } \\
17 \text { July } 1967\end{array}$ & Go station & A16940, A16855 \\
\hline J. Jeffery & 1 & January 1971 & Napier Downs Whiskey Crossing & A22045 \\
\hline J. Lanagan & 1 & $\begin{array}{l}17 \text { November } \\
1923\end{array}$ & Fitzroy River Myroodah Station & E08359 \\
\hline Long John & 1 & 1 June 1992 & Laidlaw Range & E08359 \\
\hline $\begin{array}{l}\text { Miss H. } \\
\text { Richardson }\end{array}$ & 1 & 1911 & Mt Hart & A4610 \\
\hline Mr Murphy & 2 & 30 March 1903 & NA & E00832, E00830 \\
\hline Mrs Cavalli & 4 & NA & NA & $\begin{array}{l}\text { A21884, A12321, A21884, } \\
\text { A21884 }\end{array}$ \\
\hline N Hayes & 3 & 1902 & Leopold Range & A564, A557, A558 \\
\hline P Smith & 2 & 24 February 1959 & 17 Miles from Wyndam & A16091 \\
\hline Randolph & 1 & NA & $\begin{array}{l}\text { Mt House Homestead: “Old } \\
\text { People Camp" }\end{array}$ & B3509 \\
\hline T Davis & 3 & NA & available & B2602, B2607 \\
\hline K. Akerman & 3 & October 1978 & $\begin{array}{l}\text { Myalls Creek Bore, Big Moana } \\
\text { Bore Old Cherabun Station, } \\
\text { Turkey Creek }\end{array}$ & \\
\hline K. Akerman & 4 & 1970s & NA & $\begin{array}{l}\text { UWA unprovenanced } \\
\text { Kimberley Collection }\end{array}$ \\
\hline Unknown & 1 & NA & NA & B6699 \\
\hline Unknown & 1 & 1911 & China spear no particulars & A45774 \\
\hline Unknown & 6 & NA & NA & B7852, B2617 \\
\hline Unknown & 1 & 1896 & NA & A604 \\
\hline Unknown & 1 & NA & Isdell Range & A3792 \\
\hline
\end{tabular}


Table 3. Ethnographic collection artefact frequency.

\begin{tabular}{lc}
\hline Artefact & Frequency \\
\hline Bifacial preform & 24 \\
Kimberley Point (serrate) & 50 \\
Kimberley Point (denticulate) & 1 \\
Kimberley Dentate Point & 6 \\
Edge Ground Kimberley Point & 1 \\
\hline
\end{tabular}

Table 4. Blundell collection artefacts.

\begin{tabular}{llc}
\hline Site & Artefact & Frequency \\
\hline Lennard River 12 (LR12) & Bifacial preform & 10 \\
(Blundell 1975: 232-236) & Kimberley Point (serrate) & 1 \\
& Kimberley Dentate Point & 2 \\
\hline Lennard River 9 (LR9) & Kimberley Point (serrate) & 1 \\
(Blundell 1975: 218-221) & Kimberley Dentate Point & 1 \\
\hline $\begin{array}{l}\text { Lennard River 4 (LR4) Burralumna Spring } \\
\text { (Blundell 1975: 213) }\end{array}$ & Kimberley Point (serrate) & 1 \\
\hline Lennard River 3 (LR3) & Kimberley Dentate Point & 1 \\
(Blundell 1975: 212) & & \\
\hline Mandanari and Mount Elizabeth 3 (ME3) & Bifacial preform & 24 \\
(Blundell 1975: 198) & Kimberley Point (serrate) & 2 \\
& Kimberley Dentate Point & 1 \\
\hline Wanaliri and Mount Elizabeth 2 (ME2) & Bifacial preform & 2 \\
(Blundell 1975: 192) & & \\
\hline
\end{tabular}

\section{Results}

\subsection{Ethnographic collections}

\subsubsection{Variation in serrate, denticulate, and dentate projections}

Within the ethnographic collection, complete pressure flaked bifaces $(n=57)$ could be defined with each of the three qualitative groups outlined by Akerman and Bindon (1995: 89): including serrate $(n=50)$, denticulate $(n=1)$ and dentate $(n=6)$, as well as a single edge ground point, which is the only such form known and lacks marginal projections (Akerman and Bindon 1984: 364). Twenty-one (19\%) retain hafting mastic, which does not show patterns associated with biface size $(\mathrm{H}=0.026, \mathrm{df}=1, \mathrm{p}=0.872)$. The denticulate and dentate points were each found to also have serrations on at least $38 \%$ of their margins, consistently on the distal third and occasionally $(n=1)$ between dentate projections. Neither of these trends are associated with size.

Variation in the size and shape of serrations reveals that the three projection types do cluster according to their qualitative groups (Figure 7). As shown in Figure 7 A, dentate tend to be larger, in lateral extent and distance between projections. Comparison of these metric values between the projection types reveals significant difference between the groups (Tables 5 and 6). Despite the consistent presence of small serrations on all points in the sample metric variation in the projection type supports the validity of qualitative groups proposed by Akerman and Bindon (1995: 89). 
A

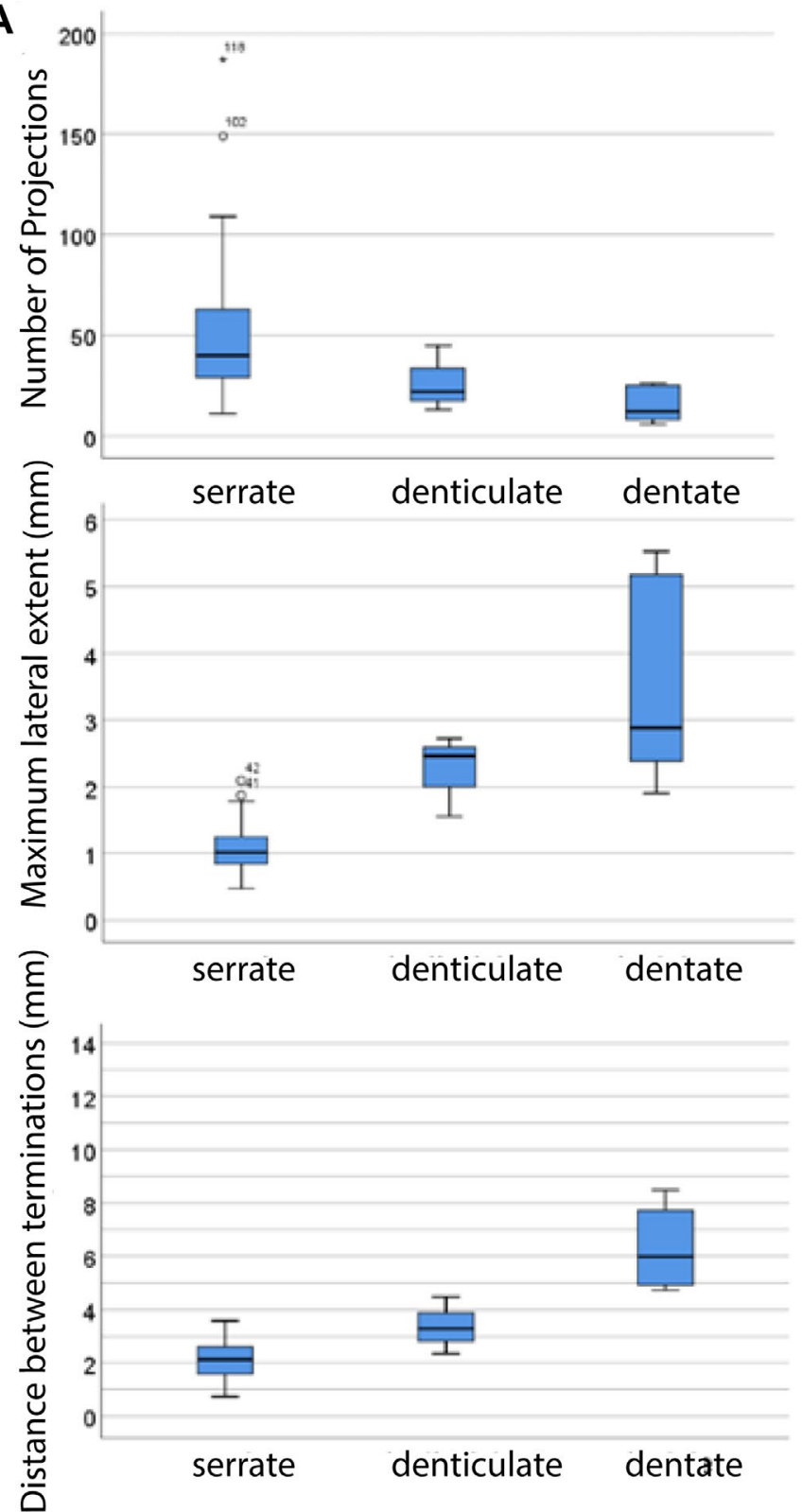

B


Figure 7. Variation in the size and shape of serrations within the ethnographic collection. A) Box plots showing grouping of projections types according to projection metrics B) Scatter plots showing biface size and total number of projections.

Table 5. Mean rank for projection types and morphological measures. Abbreviations: ${ }^{*}$ test excludes those points with more than $30 \%$ broken projections, seeing 13 exclusions.

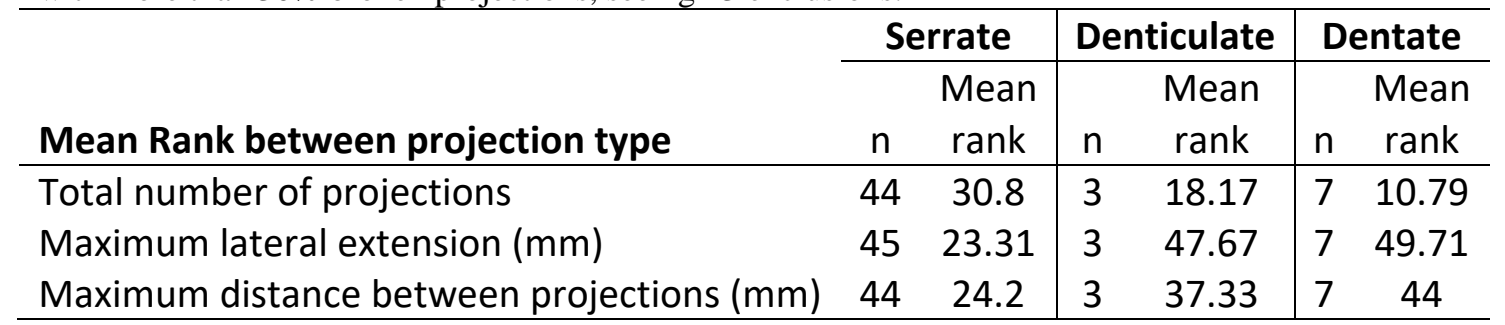


Table 6. Kruskal Wallis test of projection types and morphological measures.

\begin{tabular}{lccc}
\hline Variable & Kruskal Wallis H & df & p \\
\hline Total number of projections & 10.898 & 2 & 0.004 \\
Maximum lateral extension $(\mathrm{mm})$ & 21.239 & 2 & 0.001 \\
Maximum distance between projections $(\mathrm{mm})$ & 10.804 & 2 & 0.005 \\
\hline
\end{tabular}

Overall, size of the biface has the greatest influence on the total number of marginal projections, regardless of projection type (Figure $7 \mathrm{~B}$ ). The greater the elongation index, the greater the total number of projections $(Z=-6.393, p=0.001)$. In support of this, the total number of projections has a significant correlation with the perimeter length of the biface $\left(\mathrm{r}^{2}\right.$ $=0.554$; Pearson's Correlation: 0.429, $\mathrm{p}=0.001)$ and biface length $\left(\mathrm{r}^{2}=0.599\right.$; Pearson's Correlation: $0.751, \mathrm{p}=0.001)$. Regardless of projection type, the greater the length of the biface, the greater the number of marginal projections $(Z=-5.521, p=0.001)$. These tests suggest that overall size and available perimeter length of the thinned bifacial preform, had the greatest influence on the total number of and morphological extent of projections. Large bifaces tended be serrated, and smaller bifaces tended to have either dentate or denticulate projections; but always with some serrations.

Raw material availability (Andrefsky 1994) also had some influence on marginal projections. Glass and ceramic points were used exclusively for serrate projections and as expected produced higher numbers of serrations compared to stone points (Mann-Whitney Z $=-2.715, p=0.005)$. The ten raw material types (Table 7) reveal significant differences between the three projection types (Kruskal Wallis $\mathrm{H}=22.376, \mathrm{df}=8, \mathrm{p}=0.004$ ), generally suggesting serrations are more likely on larger, finer grained stone. Table 8 shows Kruskal Wallis test results for raw material groups, further revealing significant differences in biface elongation, total number of projections, lateral extent of projections, and distance between projections. The effect of raw material on projection type and morphology, is influenced by the size of the bifacial preform, seeing the largest points typically made from quartzite, or glass, and smaller points typically from crystal quartz, chalcedony, chert and silcrete (Figure 8). These tests reveal biface size and raw material greatly influence the final production stage of each Kimberley Point. Overall, Kimberley Points within the ethnographic sample, are seldom smaller than $50 \mathrm{~mm}$ in biface length (Figure 8) - limiting testing of biface size below $50 \mathrm{~mm}$ for varied marginal treatment. Points between 50 and $180 \mathrm{~mm}$ appear to maximise the number of projections, regardless of projection type.

Table 7. Raw material type and marginal projection type for bifaces with marginal projections. Abbreviations: Fine grained sedimentary (FGS).

\begin{tabular}{lccccc}
\hline Raw Material & $\mathbf{n}$ & \% of sample & Serrate & Denticulate & Dentate \\
\hline Quartzite & 27 & 24.5 & 10 & 0 & 1 \\
Hornfels & 6 & 5.5 & 1 & 0 & 0 \\
Chalcedony & 11 & 10 & 7 & 2 & 1 \\
Ceramic & 4 & 9.1 & 9 & 0 & 0 \\
Silcrete & 2 & 1.8 & 1 & 1 & 0 \\
Crystal quartz & 5 & 4.5 & 2 & 0 & 0 \\
Glass & 33 & 30 & 13 & 0 & 0 \\
FGS & 2 & 5.5 & 2 & 0 & 0 \\
Chert & 6 & 5.5 & 3 & 0 & 3 \\
\hline Total & $\mathbf{9 6}$ & $\mathbf{1 0 0}$ & $\mathbf{4 6}$ & $\mathbf{3}$ & $\mathbf{5}$ \\
\hline
\end{tabular}


Table 8. Kruskal Wallis tests of raw material groups against biface variables.

\begin{tabular}{lccc}
\hline Variable & Kruskal Wallis H & df & $\mathbf{p}$ \\
\hline Elongation & 20.827 & 9 & 0.013 \\
Total number of projections & 19.303 & 8 & 0.01 \\
Maximum lateral extension $(\mathrm{mm})$ & 15.920 & 8 & 0.044 \\
Maximum distance between projections $(\mathrm{mm})$ & 17.047 & 8 & 0.030 \\
\hline
\end{tabular}

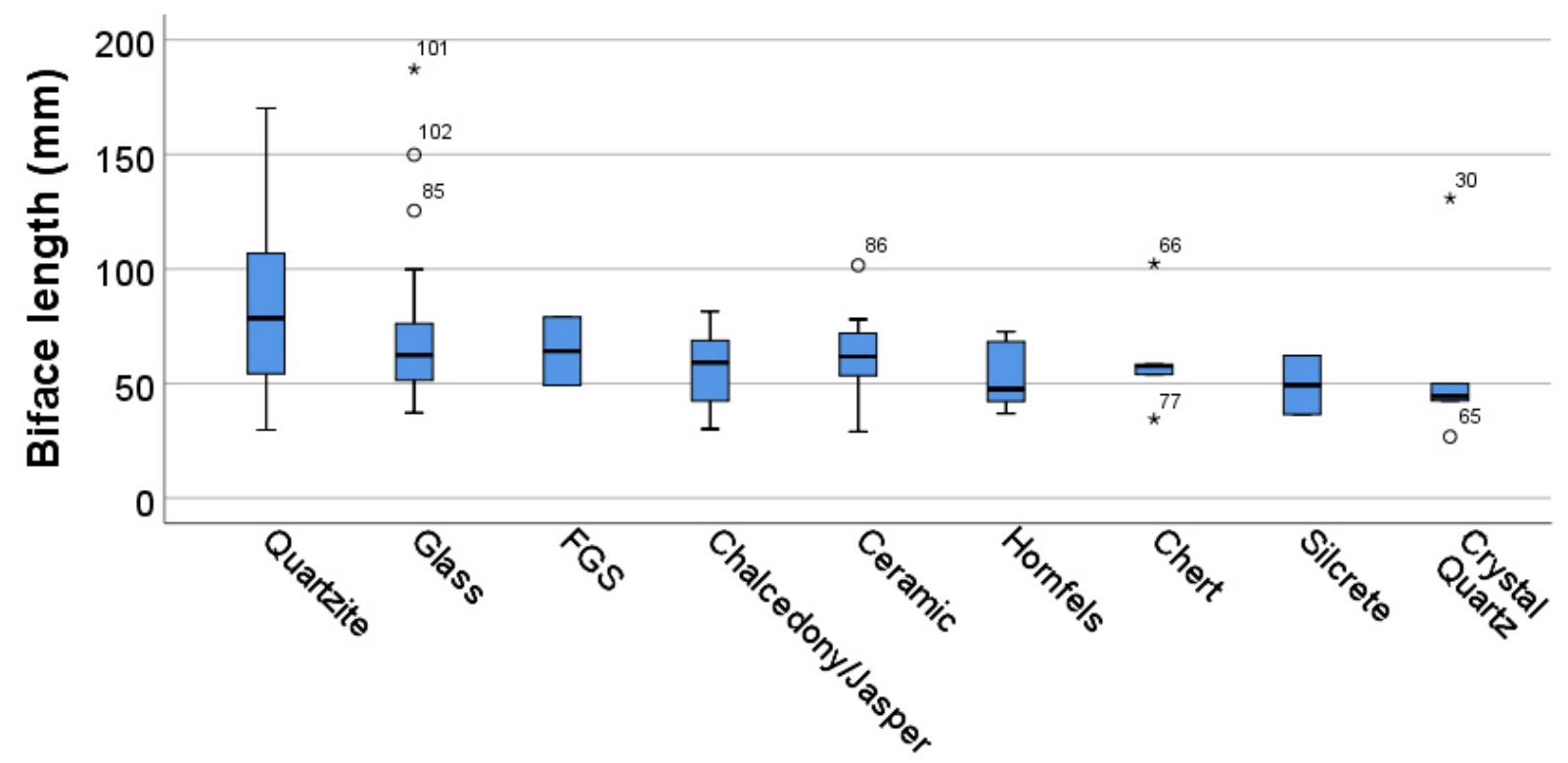

Figure 8. Biface length according to raw material.

Variability in morphological measures of the marginal projections reveals trends in regularity and standardization. For example, the standard deviations in the morphological measures of projections across the sample are less than 2.25 millimetres, for all variables. Some individual points have standard deviations for the maximum lateral extent of projections of 0.95 millimetres, illustrating great care in keeping marginal projections to a regular size.

\subsection{Blundell collections}

The number of Kimberley Points in this collection $(n=36)$ reflects their archaeological context. Bifacial preforms in these sites provide a more adequate test of the production phase model (Maloney 2019; Moore 2015), as well as further exploration of the marginal projections. Unlike the ethnographic collectors, who kept only complete Kimberley Points, Blundell (1975) systematically collected surface sites. The analysed sample used here includes all Kimberley Points and bifacial preform production phases from these surface collections (Table 4). This has excluded large numbers of other stone artefacts, including direct percussion points made on flakes and many thousand flakes and flake fragments (see Maloney 2015: 338 for full details on excluded artefacts within these sites).

In addition to a Kimberley Point (serrate) and Kimberley Dentate Point from LR9, pressure flaking tools were also recovered (Figure 9). One of which, retains the flat chisel end associated with the final production phase. No other site retained these tools, suggesting curation and transport; perhaps in wallets like those from the ethnographic collection at Tunnel Creek. Uniquely, the surface collection at Mandanari (ME3), which included 24 bifacial preforms, two Kimberley Points (serrate), and a single Kimberley Dentate Point; also 
collected two serrate points reduced from small flakes (Figure 10). These lack evidence of prior thinning. The Wanaliri (ME2) surface collection included 46 stone artefacts, which recovered two bifacial preforms.

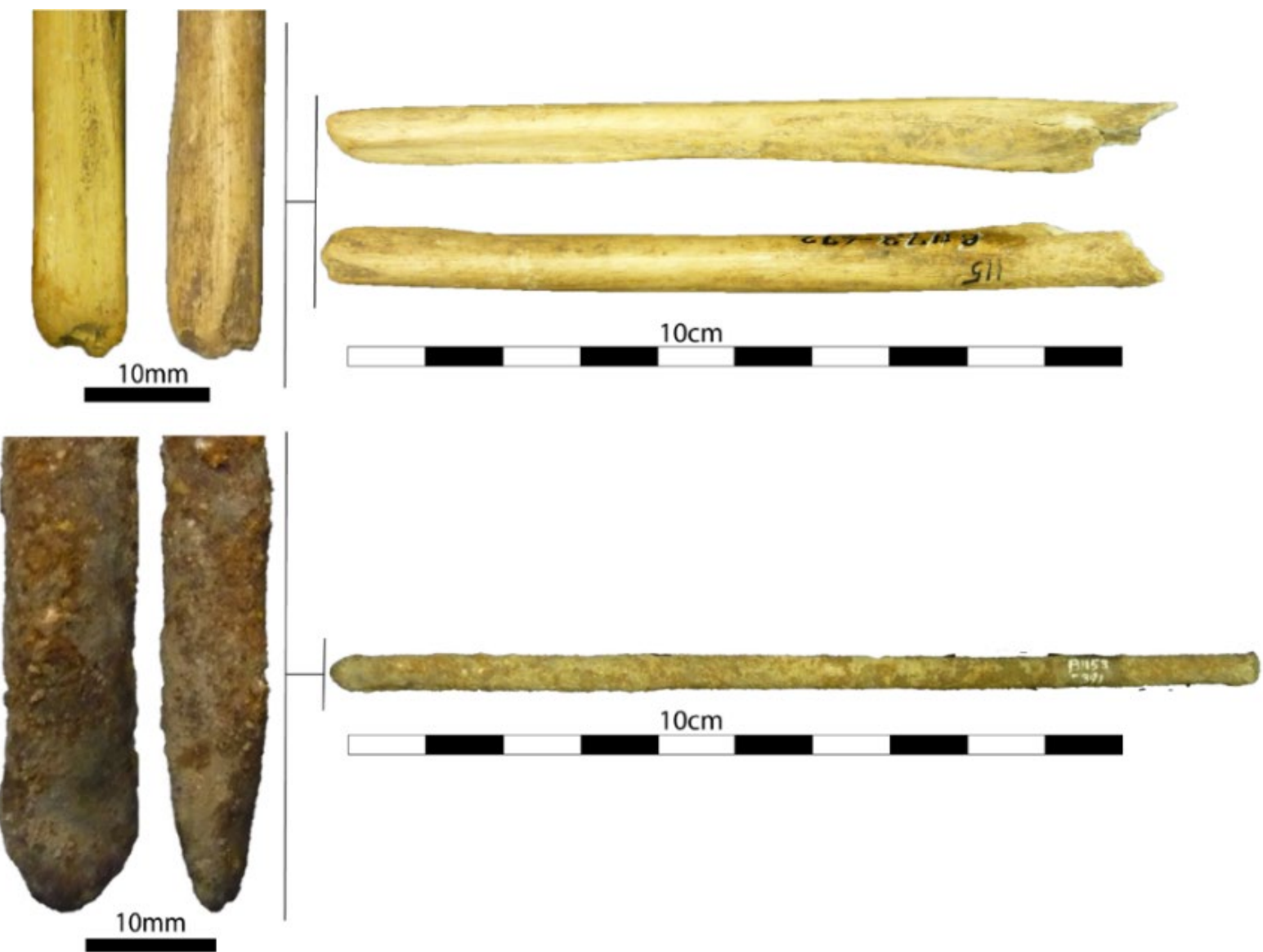

Figure 9. Bone and metal pressure flaking tools from the surface of LR9.

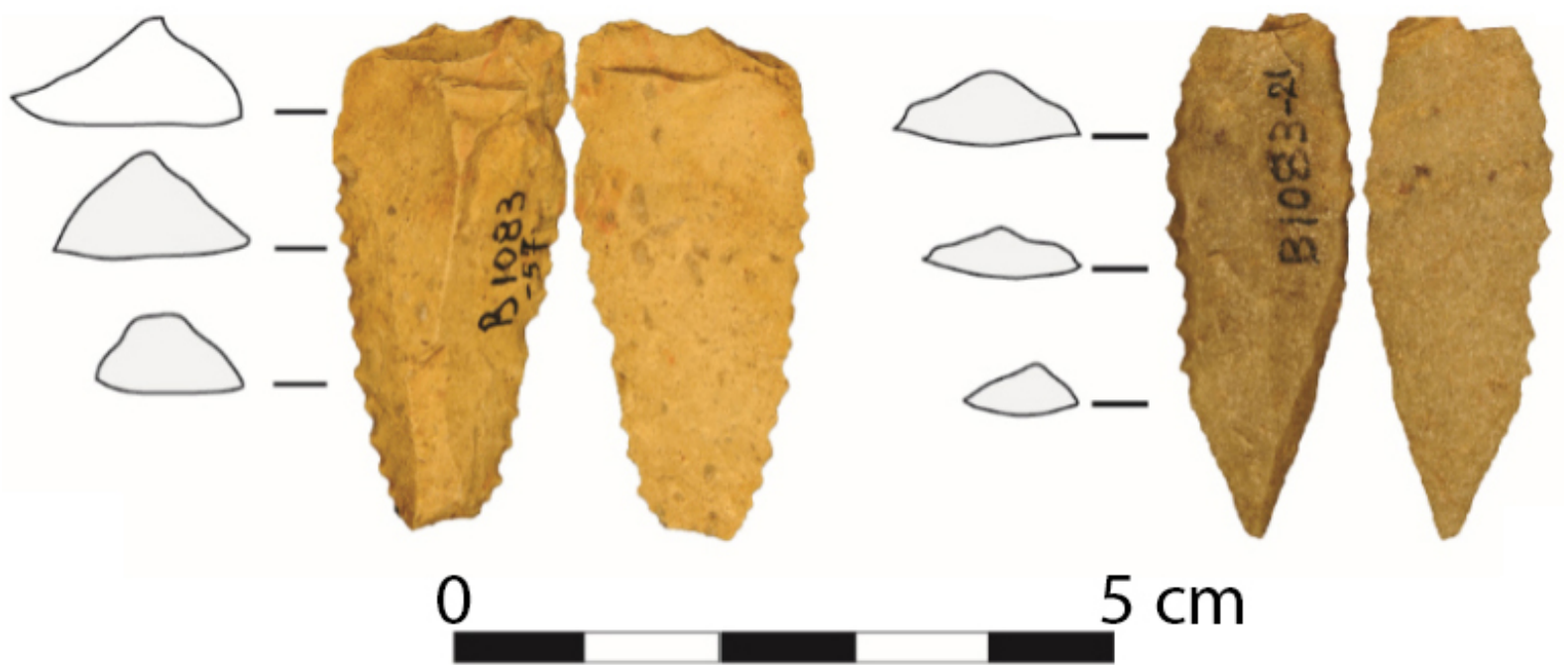

Figure 10. Serrate points made on small flakes, lacking bifacial thinning prior to pressure flaking margins. 


\subsubsection{Variation in serrate, denticulate, and dentate projections}

The Kimberley Points from the Blundell collection conform to the same morphological trends as the ethnographic sample. The three qualitative groups of marginal projections outlined by Akerman and Bindon (1995: 89): including serrate $(n=24)$, denticulate $(n=1)$ and dentate $(n=4)$ are represented. Regardless of projection type, the greater the length of the biface, the greater the number of projections $(Z=-3.883, p=0.001)$. The same trends are present for biface elongation $(Z=-2.103, p=0.035)$ and perimeter length $(Z=-3.920, p=$ 0.001 ); indicating that in this sample, biface size greatly influences the total number of marginal projections, regardless of type.

Variation in the size and shape of projections (Figure 11), reveals that the two types well represented (serrate and dentate) cluster according to their qualitative groups, although the denticulate variety is rare $(n=1)$. Comparison of morphological values between the projection types reveals significant differences between the groups (Tables 9 and 10), except in the total number of projections. This later trend could be the result of a higher number of Kimberley Points (serrate) with a small number of projections $(n=7)$, whereas the ethnographic samples' Kimberley Points (serrate) ranged from 11 to 187 projections. Elongation was also found to have significant relationships with the two projection types $(\mathrm{H}=$ $4.8, \mathrm{df}=1, \mathrm{p}=0.028$ ). Overall, these tests suggest that the qualitative projection groups do group well in the archaeological sample and that large bifaces were apparently produced to facilitate a maximum number of marginal projections.

Unlike the ethnographic collection, the raw material types from the Blundell collection do not reveal significant differences between projection metrics and raw material groups (Tables 11 and 12). This may be influenced by the comparatively smaller sample sizes, seeing comparison of projection metrics between 5 crystal quartz points and 30 quartzite points for example. These tests could imply raw material had less influence on Kimberley Points and their marginal projections. Larger quartzite blanks are not solely responsible for biface size and projection number; suggesting the number of projections are emphasized regardless of material.

As stressed by Moore (2015) and others (Akerman \& Bindon 1995: 94; Akerman et al. 2002: 19), establishing the relatively thin morphology of the biface is paramount to continued pressure flaking. Measures of width to thickness were found to have significant relationships with the total number of projections, across three points of relative thickness (Table 13). These tests demonstrate relatively thin morphologies were important for marginal projections. Without relative thickness values below $10(\mathrm{x}=3.8, \mathrm{SD}=1.7)$ along the biface, marginal projections were not produced.

The morphological tests suggest that overall size, available perimeter length, and a relatively thin morphology, had significant influence on the total number and size of projections - irrespective of projection type and in some instances regardless of raw material.

Mandanari (ME3) provides the only feasible test for the production model using metric values, with 30 bifacial preforms. No other site recovered bifacial preforms in such numbers (Table 14) to make metric comparison of production phases valid; Wanalari for example only recovered two preforms. There are two identified blank morphologies: large tabular pieces and large flakes, represented by stages 1, 1a, 2 and 2a. Metric trends between these production phases include a stepwise decrease in length and mass, as shown in Figure 12. Comparison between the intensity of bifacial reduction, measured using the Index of Invasiveness (Clarkson 2002), and increasing biconvexity in cross sections, measured by width to thickness ratios, found significant values (Table 15). These tests support the validity of the production phases being distinct phases (Shott 2017). 

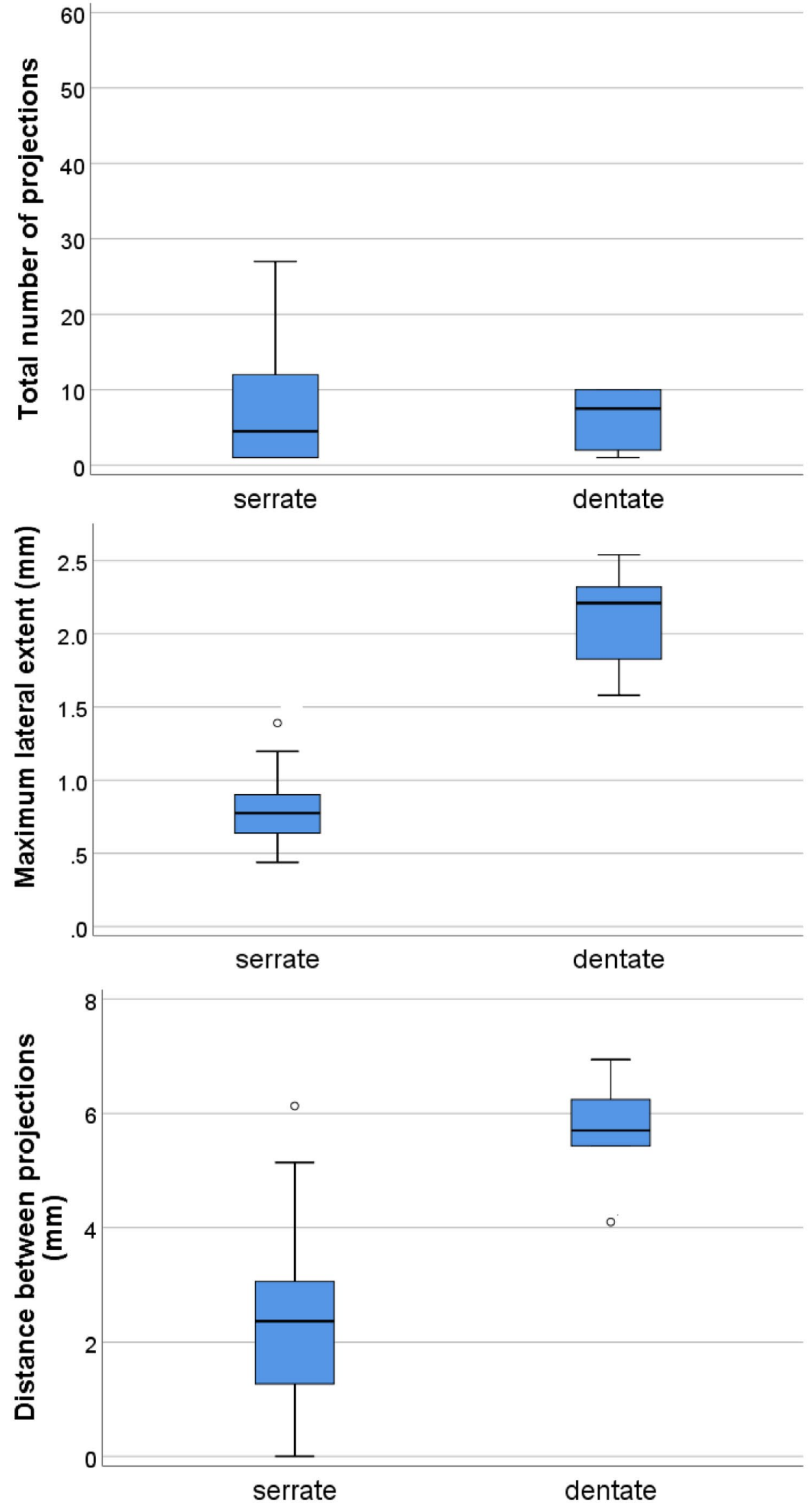

Figure 11. Metric variation of projection types. 
Table 9. Mean rank for projection metrics and raw material groups.

\begin{tabular}{lcccc}
\hline & \multicolumn{2}{c}{ serrate } & \multicolumn{2}{c}{ denate } \\
\cline { 2 - 5 } Mean rank & $\mathrm{n}$ & Rank & $\mathrm{n}$ & Rank \\
\hline Total number of projections & 26 & 16.79 & 6 & 16.83 \\
Maximum lateral extension $(\mathrm{mm})$ & 18 & 9.5 & 5 & 21 \\
Maximum distance between projections $(\mathrm{mm})$ & 22 & 11.68 & 5 & 24.2 \\
Distance between notches $(\mathrm{mm})$ & 16 & 8.63 & 5 & 18.6 \\
\hline
\end{tabular}

Table 10. Kruskal Wallis tests for raw material groups and projection metrics.

\begin{tabular}{lccc}
\hline Raw material group tests & Kruskal Wallis H & df & $\mathbf{p}$ \\
\hline Total number of projections & 0.474 & 2 & 0.789 \\
Maximum lateral extension $(\mathrm{mm})$ & 11.250 & 1 & 0.001 \\
Maximum distance between projections $(\mathrm{mm})$ & 10.168 & 1 & 0.001 \\
Distance between notches $(\mathrm{mm})$ & 9.845 & 1 & 0.001 \\
\hline
\end{tabular}

Table 11. Mean rank for projection metrics and raw material groups.

\begin{tabular}{|c|c|c|c|c|c|c|c|c|c|c|c|c|}
\hline \multirow[b]{2}{*}{ Mean Rank } & \multicolumn{2}{|c|}{ Quartzite } & \multicolumn{2}{|c|}{ Chert } & \multicolumn{2}{|c|}{ Quartz } & \multicolumn{2}{|c|}{ Glass } & \multicolumn{2}{|c|}{ Hornfels } & \multicolumn{2}{|c|}{ Ceramic } \\
\hline & $\mathrm{n}$ & Rank & $\mathrm{n}$ & Rank & $\mathrm{n}$ & Rank & $\mathrm{n}$ & Rank & $\mathrm{n}$ & Rank & $\mathrm{n}$ & Rank \\
\hline Total number of projections & 11 & 14.36 & 6 & 16.33 & 2 & 25.25 & 2 & 19.00 & 9 & 20.56 & 3 & 10.50 \\
\hline Maximum lateral extension (mm) & 4 & 13.75 & 5 & 11.40 & 1 & 22.00 & 2 & 10.00 & 2 & 8.50 & 9 & 11.67 \\
\hline Distance between projections $(\mathrm{mm})$ & 7 & 13.5 & 6 & 17.17 & 1 & 27.00 & 2 & 14.50 & 9 & 11.00 & 2 & 12.75 \\
\hline Distance between notches ( $\mathrm{mm})$ & 8 & 9.50 & 5 & 13.60 & 1 & 19.00 & 2 & 7.50 & 3 & 11.33 & 2 & 9.50 \\
\hline
\end{tabular}

Table 12. Kruskal Wallis tests for raw material groups and projection metrics.

\begin{tabular}{lccc}
\hline Raw material group tests & Kruskal Wallis H & df & p \\
\hline Total number of projections & 3.428 & 4 & 0.489 \\
Maximum lateral extension $(\mathrm{mm})$ & 2.365 & 4 & 0.669 \\
Distance between projections $(\mathrm{mm})$ & 4.509 & 4 & 0.341 \\
Distance between notches $(\mathrm{mm})$ & 3.326 & 4 & 0.505 \\
\hline
\end{tabular}

Table 13. Wilcoxon Signed Rank tests for width to thickness against total number of projections.

\begin{tabular}{lcccc}
\hline Wilcoxon Signed Rank & $\mathbf{n}$ & Mean rank & $\mathbf{Z}$ & $\mathbf{p}$ \\
\hline Proximal Width to thickness & 14 & 11.86 & -2.277 & 0.023 \\
Mid Width to Thickness & 12 & 8.50 & -2.385 & 0.017 \\
Distal Width Thickness & 12 & 13.25 & -2.016 & 0.044 \\
\hline
\end{tabular}

Table 14. Biface production phases from the Mandanari sample.

\begin{tabular}{llc}
\hline Phase & Description & Cases \\
\hline 1 & Blank morphologies of tabular pieces & 4 \\
$1 a$ & Blank morphologies of large flakes & 1 \\
2 & Bifacial reduction of tabular piece forming initial biconvex cross section & 12 \\
$2 a$ & Bifacial reduction of large flake forming initial biconvex cross section & 2 \\
3 & Bifacial reduction thins biface & 9 \\
4 & Pressure flaking used to thin biface, with collateral scars & 1 \\
5 & Pressure flaking used to form marginal projections & 1 \\
\hline
\end{tabular}



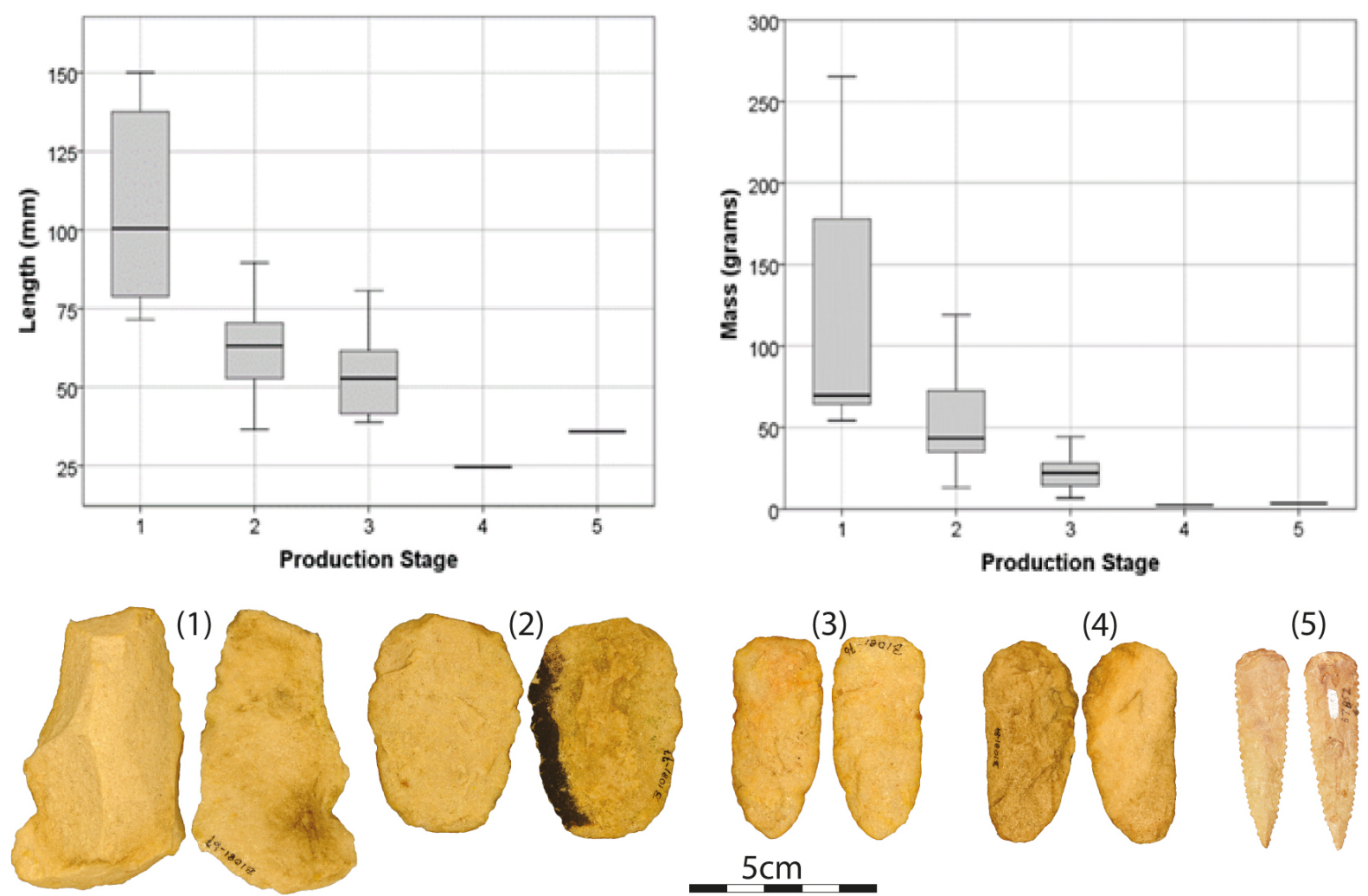

(3)

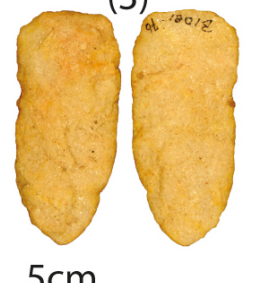

(4)

(5)

Figure 12. Decreasing biface length and mass, according to production phase. Examples of production phases from the Mandanari sample.

Table 15. ANOVA results for comparison of Index of Invasiveness and cross section ratios.

\begin{tabular}{lccc}
\hline Biface Cross Section $(\mathbf{n}=\mathbf{2 4})$ & $\mathbf{d f}$ & $\mathbf{F}$ & $\mathbf{p}$ \\
\hline Proximal Width to Thickness & 14 & 7.000 & 0.021 \\
Mid Width to Thickness & 14 & 3.478 & 0.088 \\
Distal Width to Thickness & 14 & 6.886 & 0.022 \\
\hline
\end{tabular}

\subsection{Comparison between samples}

The ethnographic sample generally had more projections per point than the Blundell sample, $(Z=-1.841, p=0.066)$, although the size of the ethnographic collection projections was generally smaller $(Z=-5.518, p=0.001)$. These tests suggest that the ethnographically collected points have more marginal projections, partly reflected by a tendency towards more Kimberley Points (serrate) made on glass and ceramic; a trend suggested previously (Akerman et al. 2002: 26). In contradiction to other claims (Akerman et al. 2002: 26), the more recent Kimberley Points, represented by glass and ceramic, also appear to be smaller in overall size than those from archaeological collections.

Projections per millimetre of biface margin $(Z=-1.342, p=0.180)$ showed no difference between samples. The marginal projections did not vary greatly in morphology between the two collections, and the same pressure flaking technique which removed small semi-circular flake adjacent projections, is evident. Overall, the marginal pressure flaking technique appears stable between the two samples and apparently adapted new materials into the production system without major change to marginal pressure flaking. 


\section{Discussion}

\subsection{Prestige and projections}

Given the lack of functional explanation and evidence (Akerman et al. 2002; Loendorf et al. 2015), the detected trends amongst marginal projections represent deliberate attempts at creating highly visible and highly distinctive tool forms, within a complex and strictly mediated production process (Maloney 2019). Morphological aspects of Kimberley Point marginal projections being associated with prestige and social signalling, find support from this study.

It was shown that the ethnographically collected points did generally have more marginal projections (Akerman et al. 2002: 26; Harrison 2004: 6). This is likely due to there being more Kimberley Point (serrate), than other marginal projection types, which typically have less projections per biface and are biased by an increase in glass and ceramic points, with exclusively serrate margins.

Point length was also thought to relate to prestige among historic Kimberley knappers, with points measuring longer than $50 \mathrm{~mm}$ being made specifically for exchange, by master craftsmen (Akerman 1979: 149-150; Akerman et al. 2002: 21). The association of biface length and prestige must also carry with it the marginal projections; as this study has shown marginal projections have a strong association with biface size, regardless of projection type and in some instances, regardless of raw material. Biface elongation, length, relative thickness, and perimeter length each influenced the number of and size of marginal projections. Large bifaces tended be serrated, and smaller bifaces tended to have either dentate or denticulate projections; but always with some serrations. A lack of points smaller than $50 \mathrm{~mm}$ prevents analysis of differential treatment for this size cut off. This study reveals large bifaces were produced to facilitate maximum numbers of marginal projections. Projections were a key part of the prestige embedded in these bifaces and the final pressure flaking phase as a public performance.

The association of Kimberley points with Wandjina religion (Akerman et al. 2002; Blundell \& Woolagoodja 2005: 129) can be linked to the Blundell collection sites, as each rock shelter has respective Wandjina figures. The presence of different bifacial preform production phases at each site, as well as complete Kimberley Points, and different pressure flaking tools; makes it difficult to assess the likelihood of virtuoso pressure flaking displays within these sites. Each production phase, including the final marginal pressure flaking, is represented, and was probably conducted within these sites.

The technique of marginal pressure flaking, removing small semi-circular flakes has not changed through time, although the adoption of glass and ceramic saw more serrate margins occur. Scars present on archaeological finds from dated contexts (Maloney et al. 2014), such as those in Figure 3, appear identical in marginal treatment to those stone points analysed in this study. It is difficult to establish when this final pressure flaking stage began to be performed as a prestige display, but it seems reasonable to suggest that biface size and marginal projections were always associated with prestige and social value. Marginal projections appear to be highly regulated across the samples, but more so on individual points. This indicates a strong homogeneity and preference for the morphology of marginal projections. These design features were likely emphasised by the production process being heavily bound to socially exclusive teaching and learning processes (Maloney 2019; Moore 2015). The lack of change represented in the sample comparison in terms of projection morphology and pressure flaking technique, may suggest prestige displays were similar in earlier times to those observed historically.

Irrespective of when pressure flaking became widely used in public displays, the archaeological data from this study as well as the now better-established chronology for 
Kimberley Points of a variety of sizes (Maloney et al. 2014); makes Harrisons (2006: 63) claim that Kimberley Points were merely “virtuoso tourist art” implausible. Moore’s (2015) explanation for the genesis of pressure flaking bifaces in the Kimberley is a much stronger argument; one that extends beyond contemporary times; and finds agreement with the wider archaeological record presented in this study and elsewhere (Maloney 2019).

This study also suggests that regardless of raw material, the final stage of pressure flaking could apply to nearly all available stone and would seek to maximise the number of marginal projections. Crabtree (1973: 11) found that while different materials may affect the initial shaping of a preform, this has little effect on variation in the techniques used in the final stages of pressure flaking and notching. Other studies have similarly found a wide variety of stone could be pressure flaked (Plew \& Woods 1985; Patterson 1998). Together with the lack of functional explanations for these marginal projections (Akerman et al. 2002; Loendorf et al. 2015); these findings strongly support marginal treatment of Kimberley Points being a social signal designed to garner prestige.

It has been argued that Kimberley Points developed after foraging risk and the need for tool material conservation diminished within the past 1,000 years (Maloney 2015, 2019). Therefore, the shift in production towards these elaborate bifaces as social symbols, represents a major change in the economic and social value of stone material. Changes within the last millennium, may have been precursors to the development of controlled access to raw materials, such as that from the Eastern Kimberley in recent times (Harrison 2002: 366).

\subsection{The Kimberley Point production phases}

To assess the validity of the Moore (2015) and Maloney (2019) production phases outside of the respective study areas, larger samples which capture more bifacial preforms would be ideal. Nonetheless, the Mandanari sample $(n=30)$ provides some indication of the validity of these production phases. Following Shott's (2017: 3) criteria for validity in a staged reduction sequence, the Mandanari sample preforms share "essential qualities that separate them from other stages”, such as phase 1 thinning of large tabular pieces, or phase 4 collateral pressure flaking for example. These qualitative observations are distinct, and do not overlap with other identified phases. The Mandanari sample also provided some indication of metric separation between identified production phases. In the other archaeological samples, metric comparison between the production phases is limited by prohibitively small sample sizes, with one or two cases representing each production phase, across different sites. In further support of the production phases, Shott's (2017: 3) staged production criteria stresses "archaeologists who contemplate the same specimens would define the same number of stages that possessed the same characteristics and would assign the specimens to the same stages”. This is generally true of Kimberley Point production, reflected in the overlapping production phases between Moore (2015) and Maloney (2019), as well as those bifacial preforms identified in the Blundell samples here, and other studies (Akerman et al. 2002; Akerman \& Bindon 1995).

\section{Conclusion}

Kimberley Points are imbued with strong social signalling qualities, reflected archaeologically in their marginal projections. Key to the virtuoso pressure flaking which garnered prestige, was the staged production process, aspects of which were likely taught in private or exclusive contexts - such as teaching and learning initiated. Morphological analysis of Kimberley Points reveals that large bifaces were produced to emphasize a maximum amount of marginal projections, within these virtuoso knapping displays. It is conceivable that these practices emerged around 1,000 years ago. 


\section{Acknowledgements}

My respects to the Bunuba, Unguumi, and Ngararin people whose traditional lands these artefacts were collected from. The author acknowledges their elders, past and present. Thank you to the staff at the Western Australian Museum for access to the collections, particularly Moya Smith and Alice Beale. Thanks to Kim Akerman for the knapping demonstration, held at the conference: "Kimberley Points: An archaeology-linguistics workshop 20-22 January 2015, Australian National University”. Thanks to ongoing support from Max Aubert's ARC Future Fellowship; the unknown 'Ice Age' artists of Borneo (FT170100025). Thanks to reviewers’ Mark Moore and Kim Akerman.

\section{References}

Akerman, K. 1978, Notes on the Kimberley stone-tipped spear focusing on the hafting mechanism. Mankind, 11: 486-489. doi:10.1111/j.1835-9310.1978.tb01190.x

Akerman, K. 1979, Heat and Lithic Technology in the Kimberleys, W. A. Archaeology \& Physical Anthropology in Oceania, 14(2): 144-151. URL: http://www.jstor.org/stable/40386342

Akerman, K. 2008, Missing the point or what to believe - the theory of the data: rationales for the production of Kimberley points. Australian Aboriginal Studies, 2: 70-79.

Akerman, K. \& Bindon, P. 1995, Dentate and related stone biface points from northern Australia. The Beagle, Records of the Museums and Art Galleries of the Northern Territory, 12: 89-99.

Akerman, K. \& Bindon, P. 1984, The Edge-ground Stone Adze and Modern Counterparts in the Kimberley Region, Western Australia. Records of the Western Australian Museum, 11(4): 357-373.

Akerman, K., Fullagar, R. \& van Gijn, A. 2002, Weapons and Wunan: production, function and exchange of Kimberley points. Australian Aboriginal Studies, 1: 14-42.

Akerman, K., \& Stanton, J. 1994, Riji and Jakoli: Kimberley pearl shell in Aboriginal Australia. Northern Territory Museum Monograph Series. Vol. 4. Northern Territory Museum, Darwin, 73 p.

Andrefsky, W.J. 1994, Raw-Material Availability and the Organization of Technology. American Antiquity, 59(1): 21-34. doi:10.2307/3085499

Balfour, H.R. 1903, On the methods employed by the natives of N.W. Australia in the manufacture of glass spear heads. Man, 1(5): 65. doi:10.2307/2839799

Balfour, H.R. 1951, A native tool kit from the Kimberley district, Western Australia. Mankind, 4(7): 273-274. doi:10.1111/j.1835-9310.1951.tb00250.x

Basedow, H. 1925, The Australian Aboriginal. F.W. Preece and Sons, Adelaide, 422 p.

Blundell, V.J. 1975, Aboriginal Adaptation in Northwest Australia. PhD at the Department of Anthropology, University of Wisconsin, Madison, 1642 p.

Blundell, V.J. \& Woolagoodj, D. 2005, Keeping The Wandjinas Fresh. Freemantle Press, Perth, 293 p. 
Carr, C. 1995, A Unified Middle-Range Theory of Artifact Design. In: Style, Society, and Person: Archaeological and Ethnological Perspectives, (Carr, C.N., J., Ed.), Plenum Press., New York: p. 171-258.

Clarkson, C. 2002, An index of invasiveness for the measurement of unifacial and bifacial retouch: a theoretical, experimental and archaeological verification. Journal of Archaeological Science, 29: 65-75. doi:10.1006/jasc.2001.0702

Clarkson, C. 2007, Lithics in the Land of the Lightning Brothers: The Archaeology of Wardaman Country, Northern Territory. Vol. 25. Terra Australis. ANU Press, 222 p. URL: http://www.jstor.org/stable/j.ctt24hb95

Crabtree, D.E. 1966, A stoneworker's approach to analyzing and replicating the Lindenmeier Folsom. Tebiwa, 9(1): 3-39.

Crabtree, D.E. 1973, Experiments in replicating Hohokam points. Tebiwa, 16(1): 10-45.

Crawford, I.M. 1968, The Art of the Wandjina. Oxford University Press, Melbourne, 144 p.

Davidson, D.S. 1935, Archaeological Problems of Northern Australia. The Journal of the Royal Anthropological Institute of Great Britain and Ireland, 65: 145-183. doi:10.2307/2843847

Davidson, D.S. \& McCarthy, F.D. 1957, The Distribution and Chronology of Some Important Types of Stone Implements in Western Australia. Anthropos, 52(3/4): 390-458. URL: https://www.jstor.org/stable/40454078

Elkin, A.P. 1948, Pressure Flaking in the Northern Kimberley, Australia. Man, 48: 110-113. doi:10.2307/2791788

Falkenberg, F. 1968, Spyd og kastetraer fra murinbataene i Nord-Australia. In: Spyd og kastetraer fra murinbataene i Nord-Australia, University of Oslo Ethnographic Museum Yearbook, Oslo, p. 15-38.

Gould, R.A. 1980, Living Archaeology. New Studies in Archaeology. Cambridge University Press, Cambridge, 270 p.

Harrison, R. 2002, Archaeology and the colonial encounter: Kimberley spear points, cultural identity and masculinity in the north of Australia. Journal of Social Archaeology, 2: 352-377. doi:10.1177/146960530200200304

Harrison, R. 2004, Kimberley Points and Colonial Preference: New Insights into the Chronology of Pressure Flaked Point Forms from the Southeast Kimberley, Western Australia. Archaeology in Oceania, 39(1): 1-11. doi:10.1002/j.18344453.2004.tb00552.x

Harrison, R. 2006, An Artefact of Colonial Desire? Kimberley Points and the Technologies of Enchantment Current Anthropology, 47(1): 63-88. doi:10.1086/497673

Haury, E.W. 1976, The Hohokam: desert farmers and craftsmen - excavations at Snaketown. University of Arizona Press, Tuscon, Arizona, 424 p.

Hiscock, P. \& Maloney, T. 2017, Australian lithic technology: evolution, dispersion and connectivity. In: Routledge Handbook of Archaeology and Globalisation, (Hodos, T., Ed.), Routledge, Abingdon, Oxon, p. 301-318.

Hoffman, C.M. 1997, Alliance Formation and Social Interaction During the Sedentary Period: A Stylistic Analysis of Hohokam Arrowpoints. Ph.D. thesis at the Department of Anthropology, Arizona State University, Arizona, 1328 p. 
Högberg, A. \& Lombard, M. 2016, Indications of pressure flaking more than 70 thousand years ago at umhlatuzana rock shelter. The South African Archaeological Bulletin, 71(203): 53-59. URL: https://www.jstor.org/stable/24894827

Hunter, P. 2014. Investigating the History of Bandicoot Bay through Glass Artefacts (Poster). presented at the AAA/ASHA Annual Conference. Cairns, Australia, 1-3 December.

Indriess, I. 1937, Over the Range: Sunshine and Shadow in the Kimberleys. Angus and Robertson, Sydney, 316 p.

Johnson, E.N. 1940, The Serrated Points of Central California. American Antiquity, 6(2): 167170. doi:10.2307/275836

Kaberry, P. 1939, Aboriginal Woman: Sacred and Profane. George Routledge and Sons Ltd, London, $352 \mathrm{p}$.

Loendorf, C., Oliver, T.J., Tiedens, S., Plumlee, R.S., Woodson, M.K. \& Simon, L. 2015, Flaked-stone projectile point serration: A controlled experimental study of blade margin design. Journal of Archaeological Science: Reports, 3: 437-443. doi:10.1016/j.jasrep.2015.07.002

Lommel, A. 1997, The Unambal: A Tribe in Northwest Australia (Translated by Ian Campbell). Takarakka Nowan Kas Publications, Carnarvon Gorge, Queensland, 122 p.

Love, J.R.B. 2009, Stone-Age Bushmen of Today: Life and Adventure Among a Tribe of Savages in North-Western Australia (Originally published 1936) (Compile by Welch, D.). Blackie \& Son, London, 200 p.

Maloney, T.R. 2015, Technological Organisation and Points in the Southern Kimberley. Ph.D. thesis at the Department of Archaeology and Natural History, Australian National University, Canberra, $351 \mathrm{p}$.

Maloney, T.R. 2019, Towards Quantifying Teaching and Learning in Prehistory Using Stone Artifact Reduction Sequences. Lithic Technology, 44(1): 36-51. doi:10.1080/01977261.2018.1564855

Maloney, T.R., O'Connor, S. \& Balme, J. 2014, New dates for point technology in the Kimberley. Archaeology in Oceania, 49(3): 137-147.

URL: https://www.jstor.org/stable/24026288

Maloney, T.R., O’Connor, S. \& Balme, J. 2017a, The effect of retouch intensity on mid to late Holocene unifacial and bifacial points from the Kimberley. Australian Archaeology, 83(1-2): 42-55. doi:10.1080/03122417.2017.1350345

Maloney, T., Dilkes-Hall, I.E. \& Davis, J. 2017b, Indigenous led archaeological excavation at Moonggaroonggoo, Gooniyandi country, Western Australia, reveals late Holocene occupation. Australian Archaeology, 83(3): 178-184. doi:10.1080/03122417.2017.1393906

Mitchell, S.R. 1949, Stone-Age Craftsmen: Stone Tools and Camping Places of the Australian Aborigines. Tait Book Co., Melbourne, 211 p.

Moore, M.W. 2015, Bifacial Flintknapping in the Northwest Kimberley, Western Australia. Journal of Archaeological Method and Theory, 22(3): 913-951.

URL: https://www.jstor.org/stable/43654205 
Nelson, N.C. 1916, Flint Working by Ishi. In: Holmes Anniversary Volume: Anthropological Essays Presented to William Henry Holmes in Honor of His Seventieth Birthday, December 1, 1916. (Hodge, F.W. Ed.), AMS Press, New York: p. 397-402.

Patterson, L.W. 1998, Raking Lithic retouch. Lithic Technology, 23(1): 27-30. URL: https://www.jstor.org/stable/23273200

Petri, H. 2011 (1954), The Dying World in Northwest Australia (Translated by Ian Campbell). Kulturgeschichtliche Forschungen (Munich, Germany); Vol. 05. Hesperian Press, Carlisle, W.A., 276 p.

Plew, M.G. \& Woods., J.C. 1985, Observation of edge damage and technological effect on pressure-flaked stone tools. In: Stone Tool Analysis: Essays in Honor of Don E. Crabtree. (Plew, M.G., Woods, J.C. \& Pavesic, M.G., Eds.), University of New Mexico Press, Albuquerque: p. 211-227.

Redmond, A. 2012, Tracking Wurnan: Transformations in the trade and exchange of resources in the northern Kimberley. In: Indigenous Participation in Australian Economies II: Historical Engagements and Current Enterprises. (Fijn, N., Keen, I., Lloyd, C. \& Pickering, M., Eds.), ANU E Press, Canberra: p. 57-72.

Rots, V., Lentfer, C., Schmid, V.C., Porraz, G. \& Conard, N.J. 2017, Pressure flaking to serrate bifacial points for the hunt during the MIS5 at Sibudu Cave (South Africa). PLOS ONE, 12(4):e0175151. doi:10.1371/journal.pone.0175151

Shott, M.J. 2017, Stage and continuum approaches in prehistoric biface production: A North American perspective. PLoSONE, 12(3):e0170947. doi:10.1371/journal.pone.0170947

Spencer, B.S. \& Gillen, F.J. 1904, The Northern Tribes of Central Australia. Macmillan, London, $784 \mathrm{p}$.

Spencer, B.S. 1928, Wanderings in Wild Australia. Macmillan, London, 455 p.

Stiener, M.C. 2014, Finding a Common Bandwidth: Causes of Convergence and Diversity in Paleolithic Beads. Biological Theory, 9(1): 51-64. doi.org/10.1007/s13752-013-0157-4

Tindale, N.B. 1965, Stone implement making among the Nakako, Ngadadjara and Pitjandjara of the Western Desert. Records of the South Australian Museum, 15: 131-164.

Tindale, N.B. 1985, Australian Aboriginal techniques of pressure-flaking stone implements: Some personal observations. In: Stone Tool Analysis: Essays in Honour of Don E. Crabtree, (Plew, M.G., Woods, J.C. \& Pavesic, M.G., Eds.), University of New Mexico Press, Albuquerque: p. 1-34.

Titmus, G. 1985, Some aspects of stone tool notching. In: Stone Tool Analysis: Essays in Honor of Don E. Crabtree. (Plew, M.G., Woods, J.C. \& Pavesic, M.G., Eds.), University of New Mexico Press, Albuquerque: p. 1-34. 